\title{
Shifts in the carbon dynamics in a tropical lowland river system (Tana River, Kenya) during flooded and non-flooded conditions
}

\author{
Naomi Geeraert $[$ - Fred O. Omengo $\cdot$ Alberto V. Borges $\cdot$ Gerard Govers $\cdot$ Steven Bouillon
}

Received: 18 January 2016/Accepted: 5 January 2017/Published online: 13 January 2017

(C) Springer International Publishing Switzerland 2017

\begin{abstract}
Rivers transport sediment and carbon (C) from the continents to the ocean, whereby the magnitude and timing of these fluxes depend on the hydrological regime. We studied the sediment and carbon dynamics of a tropical river system at two sites along the lower Tana River (Kenya), separated by a $385 \mathrm{~km}$ stretch characterized by extensive floodplains, to understand how the river regime affects within-river $\mathrm{C}$ processing as well as the $\mathrm{C}$ exchange between floodplain and river. Sampling took place during three different wet seasons (2012-2014), with extensive flooding during one of the campaigns. We measured the suspended sediment concentration, the concentration and stable isotope signature of three different
\end{abstract}

Responsible Editor: Charles T. Driscoll.

Electronic supplementary material The online version of this article (doi:10.1007/s10533-017-0292-2) contains supplementary material, which is available to authorized users.

N. Geeraert $(\bowtie) \cdot$ F. O. Omengo · G. Govers ·

S. Bouillon

Department of Earth and Environmental Sciences, KU

Leuven, Celestijnenlaan 200E, 3001 Louvain, Belgium

e-mail: naomi.geeraert@kuleuven.be

F. O. Omengo

Kenya Wildlife Service, P.O. Box 40241-00100, Nairobi, Kenya

\section{A. V. Borges}

Unité d'Océanographie Chimique, Université de Liège,

Institut de Physique (B5), 4000 Liège, Belgium carbon species (particulate and dissolved organic carbon, POC and DOC, and dissolved inorganic carbon, DIC) and other auxiliary parameters. During non-flooded conditions, the total $\mathrm{C}$ flux was dominated by POC (57-72\%) and there was a downstream decrease of the total $\mathrm{C}$ flux. DIC was dominating during the flooded season (56-67\%) and the flux of DIC and DOC coming from the inundated floodplains resulted in a downstream increase of the total carbon flux. Our data allowed us to construct a conceptual framework for the $\mathrm{C}$ dynamics in river systems, whereby nine major fluxes were identified. The application of this framework highlighted the dominance of POC during non-flooded conditions and the significant $\mathrm{CO}_{2}$ emissions during the flooded season. Furthermore, it identified the exchange of POC with the floodplain as an important factor to close the $\mathrm{C}$ budget of the river.

Keywords Carbon dynamics - Tropical rivers . Stable carbon isotopes $\cdot$ Flooded conditions

\section{Introduction}

Changes in the fluxes of carbon (C) between different reservoirs (i.e., atmosphere, ocean, and land) are at the foundation of climate change research (Denman et al. 2007). Inland aquatic ecosystems such as rivers and lakes form key connections between these three $\mathrm{C}$ pools. Initial representations of the global $\mathrm{C}$ cycle 
considered rivers as passive pipelines, delivering organic and inorganic $\mathrm{C}$ from the land to the ocean (e.g., Denman et al. 2007). However, it is now well established that processing and transformation of terrestrial $\mathrm{C}$ also takes place during transport in the river systems (Cole et al. 2007), up to the point that those systems are now considered to be global hotspots for $\mathrm{CO}_{2}$ fluxes to the atmosphere (Battin et al. 2009; Tranvik et al. 2009; Aufdenkampe et al. 2011; Raymond et al. 2013; Ciais et al. 2014; Lauerwald et al. 2015). The global annual $\mathrm{C}$ flux from

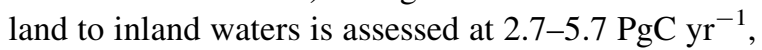
while the delivery to the ocean is estimated at $0.9 \mathrm{PgC}$ $\mathrm{yr}^{-1}$ (Aufdenkampe et al. 2011; Regnier et al. 2013; Wehrli 2013). This means that only one-third to onesixth of the terrestrial $\mathrm{C}$ delivered to inland waters effectively reaches the oceans, while the remaining amount is attributed to efflux to the atmosphere

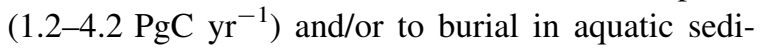

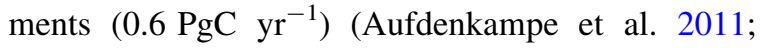
Regnier et al. 2013; Wehrli 2013). A significant yet so far poorly quantified part of the $\mathrm{CO}_{2}$ emission from river networks is fuelled by primary production from wetlands/floodplains and not from terra firme terrestrial primary production (Abril et al. 2014; Borges et al. 2015a, b).

The revisions in global riverine flux estimates in recent years are partly associated with the increasing amount of data that became available about tropical rivers and wetlands. For a long time, the Amazon river system was the main representative for tropical rivers due to a scarcity of data for other systems (e.g., Richey et al. 2002; Mayorga et al. 2005; Ellis et al. 2012). In recent years, the $\mathrm{C}$ dynamics in other tropical river systems have received more attention, and these systems often show a behaviour that differs from that of the Amazon (Borges et al. 2015a). Several surveys and monitoring campaigns have been conducted on the African continent and the datasets now span a broad range of river systems, from very large systems such as the Congo, Zambezi and Niger rivers (Coynel et al. 2005; Bouillon et al. 2012; Spencer et al. 2012; Wang et al. 2013; Zurbrügg et al. 2013; Borges et al. 2015a, b; Lambert et al. 2015), to smaller systems such as the Athi-Galana-Sabaki and Tana rivers in Kenya (Tamooh et al. 2012, 2014; Marwick 2014), the Betsiboka and Rianila basins in Madagascar (Marwick et al. 2014), the Comoé, Bia and Tanoé rivers in Ivory Coast (Koné et al. 2010), the Gambia River in West
Africa (Lesack et al. 1984), and the Nyong basin in Cameroon (Brunet et al. 2009).

Some of the studies mentioned above are longitudinal studies, i.e. the downstream variation in river $\mathrm{C}$ transport and outgassing was monitored over a relatively short time period, while other studies were based on monthly or bi-weekly sampling. While these studies have allowed to better constrain global fluxes from river systems, they do not always allow to fully capture the dynamics of $\mathrm{C}$ fluxes in such complex systems. Indeed, tropical rivers often show high interannual variability in discharge and strong seasonality whereby large variations may occur over very short time spans (Syvitski et al. 2014). Furthermore, the relationships between $\mathrm{C}$ concentrations and discharge is usually different during rising and falling stages (hysteresis), and tipping points may exist, such as the initiation of flooding, whereby different processes are activated. Depending on the nature of the hydrograph, a high temporal sampling resolution might be required to capture these variations and to uncover the patterns in those fluxes, as well as the interconnections between the different processes affecting $\mathrm{C}$ transport and outgassing in the river system. As tropical rivers also show a high inter-annual variability monitoring campaigns should ideally cover several years.

A particular point of interest here is the fact that the connectivity between lowland rivers and their floodplains varies throughout the year, with important consequences for material fluxes between the main river and its floodplain as well as for downstream transport (Tweed et al. 2015). For example, local primary production in Amazonian floodplain lakes has been identified as an important source of labile organic matter to the main river, but the floodplains are at the same time a sink for organic matter during the rising water period (Moreira-Turcq et al. 2013). The interaction between temporary flooded areas and the main river is also known to exert an important control on the delivery of organic $\mathrm{C}$, both in dissolved and particulate form (Melack and Forsberg 2001; Engle et al. 2008; Melack and Engle 2009; Pettit et al. 2011; MoreiraTurcq et al. 2013; Mora et al. 2014), as well as on greenhouse gas fluxes from the river system to the atmosphere (Melack et al. 2004; Abril et al. 2014; Borges et al. 2015a, b; Teodoru et al. 2015). The $\mathrm{CO}_{2}$ emissions of the river are supported by in situ mineralisation of terrestrial organic carbon and by $\mathrm{C}$ which was already mineralised on land or in 
floodplains and which entered the river as $\mathrm{CO}_{2}$, whereby the relative contribution of each source varies along the river continuum (Abril et al. 2014; Borges et al. 2015a, b; Hotchkiss et al. 2015; Tweed et al. 2015).

The objectives of our study are twofold. First, even though the river channel is generally considered less important than floodplains and lakes, we wanted to gain insight in the variability and significance of sediment and $\mathrm{C}$ dynamics in the river channel throughout different seasons at a high temporal resolution. Therefore, we measured daily suspended sediment as well as $\mathrm{C}$ concentrations [dissolved (DOC) and particulate (POC) organic C, dissolved inorganic $\mathrm{C}$ (DIC)] and supporting parameters during three wet season sampling campaigns, at two sites located upstream and downstream of an extensive stretch of the lower Tana River (Kenya), characterized by the presence of floodplains and the absence of major tributaries. Secondly, we used this unique dataset to assess how $\mathrm{C}$ fluxes and $\mathrm{C}$ processing are affected by different hydrological conditions. This was achieved by setting up a $\mathrm{C}$ budget framework of the river channel which extricates the contrasts in $\mathrm{C}$ dynamics while it also helps to identify gaps and uncertainties in our understanding.

We consider the Tana River as an appropriate study area, as it comprises a relatively large river system (ca. $1100 \mathrm{~km}$ in length), which experiences a pronounced seasonality in discharge, resulting in two wet seasons per year. Moreover, the river segment under consideration (approximately $385 \mathrm{~km}$ between our two sampling points) has no permanent tributaries and relative little human disturbance, so that downstream variations can be attributed to within-river $C$ processing and/or interactions between the river and the floodplain, which becomes partially flooded during high water levels and is important for regulating sediment and $\mathrm{C}$ transformation and transport further downstream (Bouillon et al. 2009; Tamooh et al. 2012, 2013, 2014).

\section{Materials and methods}

Study area and time frame

The Tana River ( $\sim 1100 \mathrm{~km}$ long), located in the south-eastern part of Kenya, has a catchment area of ca. $95,500 \mathrm{~km}^{2}$ (Fig. 1). The upper catchment ( $\sim 25 \%$ of the area) is characterized by the high altitudes of the Aberdare Mountain Range ( $3500 \mathrm{~m}$ ), Mount Kenya $(\sim 5200 \mathrm{~m})$ and the Nyambene Hills $(\sim 2500 \mathrm{~m})$. The area is built up of a Precambrian basement and Tertiary and Quaternary volcanic rocks. Many tributaries are draining the hillslopes in the upper catchment. The vegetation of the upper catchment consists, along an altitudinal gradient, of open tree vegetation and rain fed agriculture in the lower areas, dense forest at higher altitude and moorlands/grasslands in the highest areas. Five reservoirs for the production of electricity were constructed between 1968 and 1988 at altitudes between 1055 and $700 \mathrm{~m}$, of which Masinga Reservoir, with a surface area of $125 \mathrm{~km}^{2}$, is the largest. When the altitude of the river drops below $250 \mathrm{~m}$, the river starts to meander through an extended and vegetated floodplain (ca. $1000 \mathrm{~km}^{2}$ ), which gets partially flooded during high water levels (Omengo et al. 2016) and is built up of Quaternary sediments. From here on, no permanent tributaries are present and the vegetation outside of the floodplain consists of semi-arid savannah. Downstream of Garsen, the river forms a deltaic system before it drains into the Indian Ocean.

The discharge in the lower Tana River depends mainly on the precipitation in the upper catchment as the annual rainfall in the mountains can reach $1800 \mathrm{~mm} \mathrm{yr}^{-1}$, while it is less than $400 \mathrm{~mm} \mathrm{yr}^{-1}$ around Garissa (World Bank Climate Variability Tool 2015). Two wet seasons, associated with the monsoons, occur from April to June (long wet season) and from October to December (short wet season). Interannual variability in rainfall is very high, as for example in Embu (at an elevation of ca. $1500 \mathrm{~m}$ ), the standard deviation on the annual rainfall $(431 \mathrm{~mm})$ is almost half of the annual average rainfall $(1001 \mathrm{~mm}$, World Bank Climate Variability Tool 2015).

Sampling took place in the lower Tana River at the bridges in Garissa and Garsen (Fig. 1). The upstream catchment areas are $32,500 \mathrm{~km}^{2}$ at Garissa and $81,700 \mathrm{~km}^{2}$ at Garsen, representing 34 and $86 \%$ of the total Tana River Basin. Despite the larger catchment area, the discharge in Garsen is generally lower than in Garissa due to the high potential evapotranspiration which largely exceeds the rainfall in the lower Tana River (DHV 1986) and likely also due to infiltration (Leauthaud et al. 2013).The river length between the sites is approximately $385 \mathrm{~km}$, which 


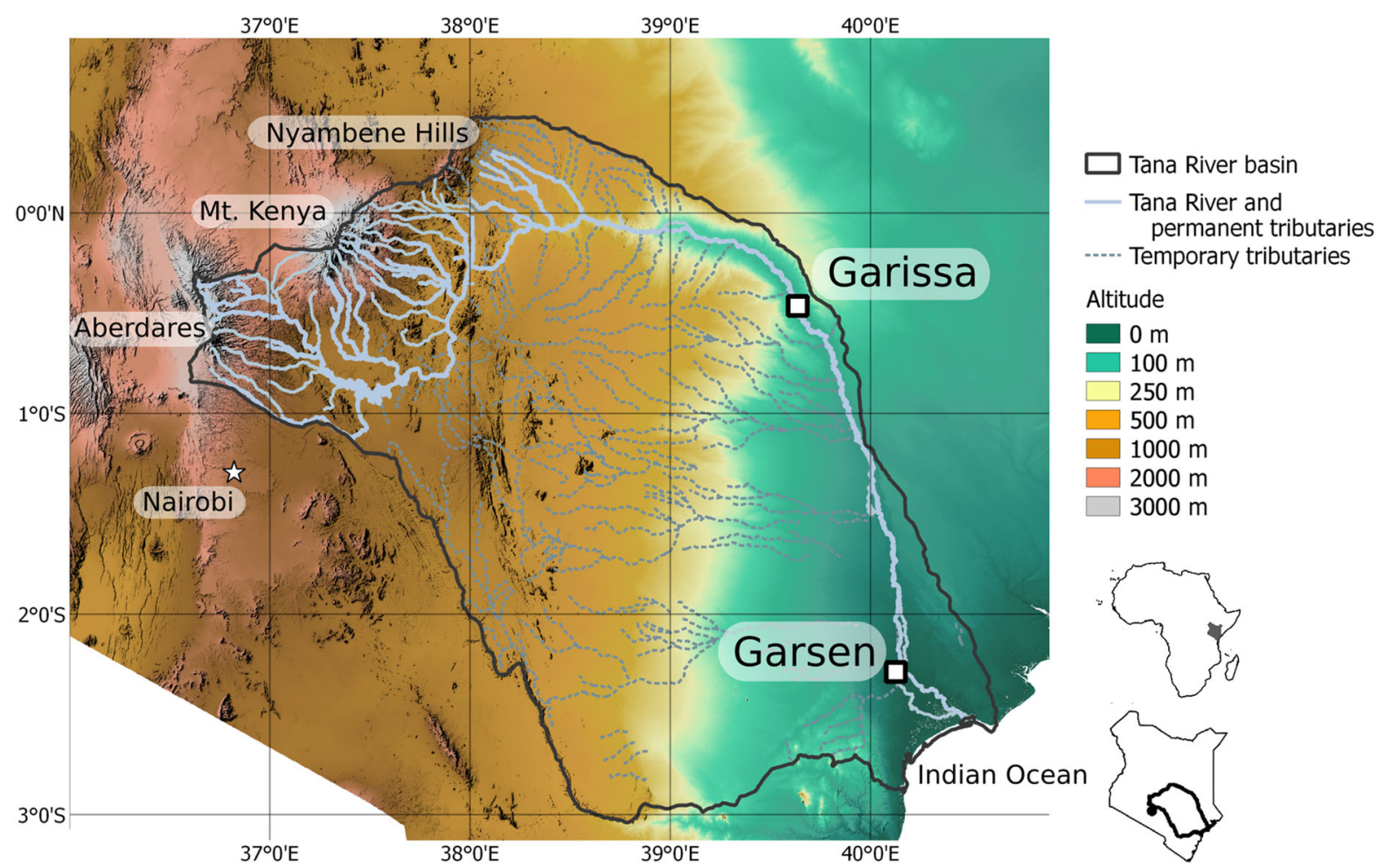

Fig. 1 The Tana River basin with the indication of the two sampling sites, Garissa and Garsen, along the Lower Tana River

corresponds to a water travel time of ca. 5 days during non-flooded conditions based on the difference in timing of discharge peaks. This is consistent with the average water speed of $1.29 \pm 0.25 \mathrm{~m} \mathrm{~s}^{-1}$ at Garissa $(\mathrm{n}=11)$ and $1.14 \pm 0.23 \mathrm{~m} \mathrm{~s}^{-1}$ at Garsen $(\mathrm{n}=25)$, measured with an acoustic Doppler current profiler (ADCP, Teledyne RDI RiverRay).

Three sampling campaigns with concurrent daily measurements in both sites were carried out for a period of 37, 52, and 45 days, respectively, during the short wet season in 2012 (October-November), and the long wet seasons in 2013 (May-June) and 2014 (April-May). The maximum areal extent of floodplain inundation, estimated based on the 15-day total discharge, was approximately 50, 290 and $20 \mathrm{~km}^{2}$ for the monitored wet seasons in 2012, 2013 and 2014 (Omengo et al. 2016).

Sampling and analysis

The water height was recorded using a stage board mounted on a bridge pillar. Rating curves for the conversion of water height to discharge were constructed for each location based on manual discharge measurement by the Water Resources Management Authority (WRMA) in Garissa (19 measurements) and own discharge measurements with an ADCP (Teledyne RDI RiverRay, 11 measurements in Garissa, 28 measurements in Garsen). ADCP measurements were made from the bridge and repeated at least 4 times per discharge measuring date so that an accuracy of at least $5 \%$ with respect to the average discharge was obtained.

Grab water samples were taken daily at the water surface with a Niskin sampler or bucket in the middle of the river. Sediment concentration sampling across a river profile showed no significant variations in concentration with depth or lateral position (Geeraert et al. 2015). Temperature, $\mathrm{pH}$ and conductivity were measured with a multimeter (YSI Professional Plus). Calibration of the $\mathrm{pH}$ probe was based on National Bureau of Standards (NBS) buffers (NBS4 and NBS7). Dissolved oxygen was measured with a YSI ProODO, calibrated on water-saturated air. Measurements of the total suspended matter (TSM) load were obtained by filtering $200-250 \mathrm{~mL}$ of water on pre- 
weighed, pre-combusted $\left(4 \mathrm{~h}\right.$ at $\left.450{ }^{\circ} \mathrm{C}\right)$ Whatman $\mathrm{GF} / \mathrm{F}$ filters (47 $\mathrm{mm}$ diameter; pore size: $0.7 \mu \mathrm{m}$ ). They were air-dried in the field and later oven-dried $\left(50{ }^{\circ} \mathrm{C}\right)$ in the laboratory before re-weighing.

A volume of $\sim 25 \mathrm{~mL}$ water was filtered for later determination of particulate organic carbon (POC), particulate nitrogen $(\mathrm{PN})$ and stable $\mathrm{C}$ isotope signatures $\left(\delta^{13} \mathrm{C}\right)$ of POC on pre-combusted Whatman $\mathrm{GF} / \mathrm{F}$ filters ( $25 \mathrm{~mm}$ diameter; pore size: $0.7 \mu \mathrm{m}$ ). The filters were air-dried in the field and oven-dried $\left(50{ }^{\circ} \mathrm{C}\right)$ before further analysis. Inorganic $\mathrm{C}$ was removed from the filters by exposing them to $\mathrm{HCl}$ fumes in a desiccator. Subsequently, the dried filters were packed in Ag cups for analysis on an elemental analyserisotope ratio mass spectrometer (EA-IRMS, ThermoFinnigan Flash HT and Delta V Advantage). The signal of the thermal conductivity detector (TCD) of the elemental analyzer was used for quantifying the concentrations of $\mathrm{PN}$, while the $\mathrm{m} / \mathrm{z} 44,45,46$ signal on the IRMS was used for determining POC and $\delta^{13} \mathrm{C}_{\text {POC. }}$. Calibrations for the concentrations were based on acetanilide standards. Sucrose (IAEA-C6, $\delta^{13} \mathrm{C}=-10.4 \%$ ) and acetanilide $\left(\delta^{13} \mathrm{C}=-27.65 \%\right.$ ) were used for the calibration of $\delta^{13} \mathrm{C}$ data. Reproducibility of the $\delta^{13} \mathrm{C}$ measurements was typically better than $0.2 \%$. POC/PN ratios are reported as mass/mass ratios.

Water samples for dissolved organic carbon (DOC) and $\delta^{13} \mathrm{C}_{\mathrm{DOC}}$ were pre-filtered on $47 \mathrm{~mm}$ pre-combusted GF/F filters and subsequently filtered with $0.2 \mu \mathrm{m}$ syringe filters. The samples were stored in glass vials with Teflon-coated screw caps and $50 \mu \mathrm{L}$ of $\mathrm{H}_{3} \mathrm{PO}_{4}$ was added for preservation. Analysis of DOC and $\delta^{13} \mathrm{C}_{\mathrm{DOC}}$ was performed on a wet oxidation TOCanalyzer (IO Analytical Aurora $1030 \mathrm{~W}$ ) coupled with an isotope ratio mass spectrometer (ThermoFinniganDeltaV Advantage). Calibrations were based on a 2-point calibration (IAEA-C6, $\delta^{13} \mathrm{C}=-10.4 \%$ and an internal sucrose standard, $\delta^{13} \mathrm{C}=-26.99 \%$ ). Based on replicates of the standards, the error on the concentration measurements was less than $3 \%$ and the standard deviation on the $\delta^{13} \mathrm{C}$ measurements better than $0.2 \%$.

Samples for $\delta^{13} C_{\text {DIC }}$ were taken by gently overfilling $12 \mathrm{~mL}$ glass headspace vials and poisoning them with $20 \mu \mathrm{L} \mathrm{HgCl}$. Prior to analysis, a helium headspace was created in the vials and $\sim 300 \mu \mathrm{L}$ of $\mathrm{H}_{3} \mathrm{PO}_{4}$ was added. After overnight equilibration, $\sim 1 \mathrm{~mL}$ of headspace was injected into the He flow of an EA-
IRMS (ThermoFinnigan Flash HT and Delta V Advantage). The results were corrected for isotopic equilibration between the dissolved $\mathrm{CO}_{2}$ and the gaseous $\mathrm{CO}_{2}$ (Gillikin and Bouillon 2007). Calibration of the measurements was done by certified reference material LSVEC $\left(\delta^{13} \mathrm{C}=-46.6 \%\right.$ ) and IAEA-CO- 1 $\left(\delta^{13} \mathrm{C}=+2.492 \%\right)$.

The $\mathrm{pCO}_{2}$ of the water was measured in the field with a headspace technique (Teodoru et al. 2009; Abril et al. 2015) on a Li-Cor LI-820 gas analyzer. Three replicate syringes were filled with $30 \mathrm{~mL}$ of water and $30 \mathrm{~mL}$ of air with known $\mathrm{pCO}_{2}$ (either ambient air, or $\mathrm{CO}_{2}$-free air obtained by pumping air through a chemical $\mathrm{CO}_{2}$ trap), and were shaken for $2 \mathrm{~min}$ to equilibrate. Subsequently, the headspace was injected in the gas analyzer. Afterwards, the concentration in the water was calculated based on Henry's law and taking into account the $\mathrm{pCO}_{2}$ of the headspace gas before and after equilibration, temperature and the ambient pressure. Total alkalinity (TA) samples were pre-filtered on a pre-combusted GF/F filter. Following filtration at $0.2 \mu \mathrm{m}$ with a syringe filter, the samples were stored in HDPE bottles. Analysis was done by automated electro-titration on $50 \mathrm{~mL}$ samples with $0.1 \mathrm{~mol} \mathrm{~L}^{-1} \mathrm{HCl}$ as titrant. Hereafter, the unit of TA is given as $\mu \mathrm{mol} \mathrm{kg}{ }^{-1}$ corresponding to the $\mu \mathrm{mol}$ of protons of strong acid needed to titrate all bases present in one $\mathrm{kg}$ of sample water to the second equivalence point of carbonic acid. Based on replicates, the reproducibility is estimated better than $\pm 3 \mu \mathrm{mol} \mathrm{kg}{ }^{-1}$. The total dissolved inorganic carbon (DIC) concentrations were calculated from $\mathrm{pCO}_{2}$ and TA measurements by using the thermodynamic constants for freshwater from Millero (1979) in CO2SYS (Lewis and Wallace 1998).

Community respiration rates were determined by measuring the decrease of dissolved oxygen in the dark over time. Therefore, at least nine glass bottles with stoppers were gently overfilled with river water, and the dissolved oxygen concentration of four bottles was measured immediately with an optical sensor (YSI ProODO). The remaining bottles were stored (without agitating) in a cooler box filled with river water to maintain ambient temperature, and dissolved $\mathrm{O}_{2}$ concentrations were measured after $\sim 24 \mathrm{~h}$. To take into account that complex molecules require more oxygen to oxidise, the $\mathrm{O}_{2}$ consumption is divided by a respiratory ratio $\left(\mathrm{O}_{2}: \mathrm{C}\right)$ of 1.3 in order to obtain $\mathrm{CO}_{2}$ equivalent respiration rates (Richardson et al. 2013), 
although we acknowledge this ratio is variable in freshwaters (Berggren et al. 2012).

In 2013 and 2014, samples for major elements $\left[\mathrm{Ca}^{2+}, \mathrm{Mg}^{2+}\right.$ and dissolved $\mathrm{Si}$ (DSi)] were taken every other day by filtering water on $47 \mathrm{~mm}$ pre-combusted $\mathrm{GF} / \mathrm{F}$ filters, followed by filtration on $0.2 \mu \mathrm{m}$ syringe filters. No preservation was added in the field, but samples were acidified with ultrapure $\mathrm{HNO}_{3}$ prior to analysis by inductively coupled plasma mass spectrometry (ICP-MS, Agilent 7700x).

Statistical calculations were done in $\mathrm{R}$ (version 3.0.0). Average values are reported \pm 1 standard deviation. Pearson correlation coefficients ( $r$ ) were calculated to test for correlations between parameters, while Welch two sample $t$ tests were applied to test for significant differences either between the upstream and downstream locations (paired $t$ test), or between different hydrological conditions at one sampling location (unpaired $t$ test).

\section{Conceptual framework}

The aforementioned measurements of $\mathrm{C}$ concentrations and auxiliary parameters allow us to set up a $\mathrm{C}$ budget for the stretch of the river channel. For each of the $\mathrm{C}$ species (POC, DOC and DIC), there should be a balance in the $\mathrm{C}$ fluxes:

$\mathrm{F}_{\text {in }}=\mathrm{F}_{\text {out }}+\mathrm{F}_{\text {lat }}+\mathrm{F}_{\text {int }}$

whereby $F_{\text {in }}$ and $F_{\text {out }}$ are longitudinal fluxes at the inlet and outlet of the stretch, $\mathrm{F}_{\text {lat }}$ includes all the lateral fluxes (i.e. between the riverine $\mathrm{C}$ and external $\mathrm{C}$ pools) and $F_{\text {int }}$ represents all the internal fluxes (i.e. between the different $C$ pools inside the river). The lateral and internal fluxes depend on the $\mathrm{C}$ species and occur simultaneously over the entire river stretch (Fig. 2). As some of the terms can be subject to interpretation, we will discuss them briefly in this section, while details of the calculations are explained in the following section

(1) and (2) The longitudinal fluxes per species at the inlet and outlet are the foundation of the framework. As the calculations of these longitudinal fluxes do not require many assumptions, and given the high temporal sampling resolution of our study, the uncertainty on these estimates is only determined by the uncertainty on the discharge and the concentration measurements.

POC, which is strongly linked to the TSM load, is subject to deposition and resuspension cycles (Moreira-Turcq et al. 2013; Mora et al. 2014). Our sampling strategy of TSM and POC measurements did not allow to calculate gross deposition and resuspension, but resulted in a net flux, which can be either towards or away from the river.

(4) Primary production in the water column will transfer $\mathrm{C}$ from the DIC pool to the POC pool (Pettit et al. 2011).

Rock weathering in the floodplain will result in DIC inputs to the river through the groundwater or floodwater (Liu et al. 2011). During carbonate weathering, between 1 and $2 \mathrm{~mol}$ of $\mathrm{HCO}_{3}{ }^{-}$ is transferred to the river per mole of $\mathrm{Ca}^{2+} / \mathrm{Mg}^{2+}$, depending on whether the $\mathrm{CO}_{2}$ to initiate the reaction is derived from the river water or from soil/ground water (Garrels and Mackenzie 1971). Weathering of silicate minerals increases $\mathrm{HCO}_{3}{ }^{-}$concentrations with one mole per mole of $\mathrm{CO}_{2}$ consumed during the weathering, and at the same time generates DSi. The stoichiometric relationship between DSi and produced alkalinity as well as the relative release of cations (e.g., $\mathrm{Ca}^{2+}, \mathrm{Mg}^{2+}, \mathrm{Na}^{+}, \mathrm{K}^{+}$) varies depending on the composition of the silicate minerals considered, complicating the quantification of the weathering fluxes.

(6) The degradation of POC will result in the production of DIC and DOC (Ward et al. 2013). A distribution coefficient to allocate the decomposed POC over DOC and DIC can be a tuning parameter in modelling studies.

(7) The mineralization of DOC transfers C to the DIC pool and the POC pool (as bacterial biomass). The bacterial growth efficiency (BGE), i.e., the fraction of $\mathrm{C}$ taken up by bacteria and 
Fig. 2 Conceptual framework representing the main carbon fluxes in the lower Tana River system

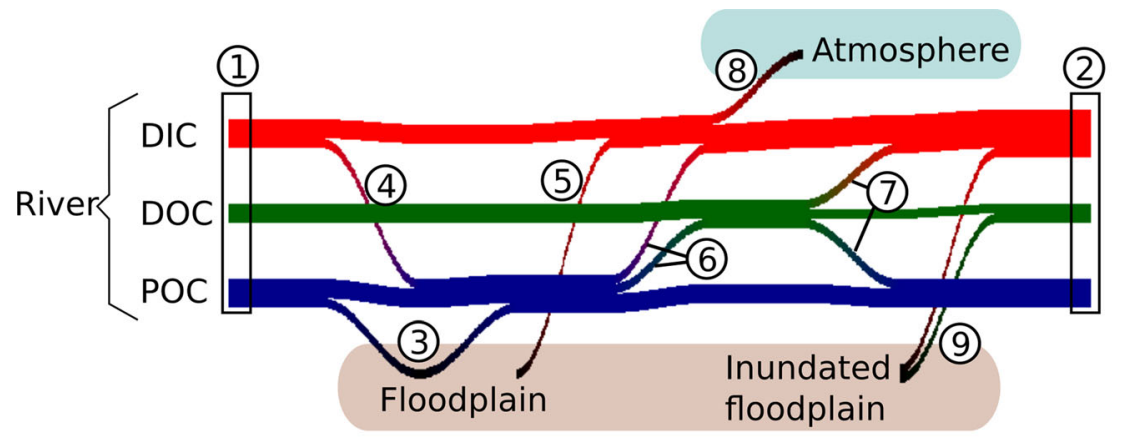

1. carbon input

2. carbon output

3. deposition POC/ mobilisation POC
4. primary production 7. respiration DOC

5. weathering 8. $\mathrm{CO}_{2}$ evasion

6. degradation POC 9. dissolved flux (flooding) converted into biomass, ranges between 0.02 and 0.40 for tropical systems (Amado et al. 2013).

(8) When the river water is oversaturated in $\mathrm{CO}_{2}$, DIC transiting the river section will be lost through $\mathrm{CO}_{2}$ evasion.

(9) During flooded conditions, floodplain water can transport large amounts of $\mathrm{C}$ from the floodplain to the river (Moreira-Turcq et al. 2013; Hotchkiss et al. 2015). This flux consists of DIC as a result of floodplain respiration and DOC. Two other fluxes between the inundated floodplain and the river, the flooding-induced increase of DIC flux due to weathering and the POC flux, are already taken into account in fluxes (5) and (3).

Flux calculations

\section{Longitudinal fluxes}

To calculate the longitudinal fluxes of sediment and C over the three observation periods in each sampling site, data gaps had to be filled. Single day gaps in discharge $(n=2), \operatorname{TSM}(n=4)$ and DIC $(n=2)$ were filled by averaging the values of the surrounding days. Larger gaps in the POC measurements $(n=8)$ were filled based on a linear regression between all TSM and POC measurements of the respective campaign and location. As no systematic pattern could be detected in DOC values, missing values in DOC $(n=22)$ were filled with the median concentration over the whole dataset $\left(2.53 \mathrm{mg} \mathrm{L}^{-1}\right)$. The large gap in DIC values in Garissa $(n=19)$ was filled by a linear interpolation between the conductivity and the DIC concentration over the three seasons in Garissa.

Daily fluxes were calculated by multiplying the daily discharge with the daily concentration of the TSM or C species. Fluxes over each campaign were obtained by summing the daily fluxes. Monte Carlo simulation was used for the error propagation analysis, whereby a random value was picked out of a uniform distribution within a $\pm 15 \%$ range of the observed value for discharge (based on the observed scatter around the regression line of the discharge rating curve) and within $\pm 5 \%$ of the observed value for all concentration measurements (based on the accuracy of the measurements). The calculation of the seasonal fluxes was repeated 1000 times with randomized discharge and concentration and the standard deviation on those values is representative for the precision of the fluxes.

\section{Lateral fluxes}

To estimate the magnitude of POC flux between the river channel and the floodplain, we assumed that the POC was strongly bound to the TSM and therefore the POC was exchanged with the floodplain in the same relative proportion as the change in TSM. We thereby presume that there are no other processes which reduce the mass of the TSM and that the POC content (\%) of the TSM is constant over the whole stretch. 
The $\mathrm{C}$ influx due to carbonate weathering can be calculated from the difference in $\mathrm{Ca}^{+2}$ and $\mathrm{Mg}^{2+}$ fluxes at the upstream and downstream end of the section as two bicarbonate anions are produced for each $\mathrm{Ca}^{2+}$ or $\mathrm{Mg}^{2+}$ cation that is formed according to:

$$
\begin{aligned}
& (\mathrm{Ca}, \mathrm{Mg}) \mathrm{CO}_{3}+\mathrm{CO}_{2}+\mathrm{H}_{2} \mathrm{O} \\
& \quad=>\left(\mathrm{Ca}^{2+}, \mathrm{Mg}^{2+}\right)+2 \mathrm{HCO}_{3}^{-} .
\end{aligned}
$$

As the concentrations of $\mathrm{Ca}^{+2}, \mathrm{Mg}^{2+}$ and DSi were measured every other day in 2013 and 2014, the flux of those elements on days without measurement was calculated based on linear regressions between the discharge and the daily flux of each element, with separate regression lines for each site and each year (4 regressions per element).

In order to integrate the estimated $\mathrm{CO}_{2}$ exchange between the river water surface and the atmosphere, a river surface area had to be determined. Measurements with the ADCP at Garissa and Garsen indicated that the width of the river varied with ca. $10 \%$ between high and low discharge. As this change was small relative to the uncertainties associated with the flux per square meter, we assumed a constant river surface area which did not change with discharge. The river surface area was manually delineated in Google Earth, resulting in a total river surface area of $38.5 \mathrm{~km}^{2}$, which is equivalent to an average river width of $100 \mathrm{~m}$. Only outgassing from the main river channel was taken into account in the estimates: outgassing during flooding conditions is therefore likely to be underestimated.

The outgassing flux over the whole river stretch is initially calculated using estimates of outgassing rates (per unit surface area) calculated from the data collected on both sampling sites. The average value of these estimates will provide a realistic value of the total flux but this estimate assumes that the fluxes vary linearly between both sites.

The $\mathrm{CO}_{2}$ flux is calculated as:

$F_{\mathrm{CO} 2}=k * \mathrm{H}_{\mathrm{CO} 2} *\left(p \mathrm{CO}_{2(\text { water })}-p \mathrm{CO}_{2(\text { atm })}\right)$

whereby

$$
\begin{aligned}
& k=k_{600} *\left(\frac{600}{S c}\right)^{0.5} \\
& k_{600}=V * S * 2841 \pm 107+2.02 \pm 0.209
\end{aligned}
$$

$V=0.19 * Q^{0.29}$

$\mathrm{F}_{\mathrm{CO} 2}$ is the water-air flux of $\mathrm{CO}_{2}\left(\mu \mathrm{mol} \mathrm{m}{ }^{-2} \mathrm{~h}^{-1}\right), k$ is the gas transfer velocity of $\mathrm{CO}_{2}$ at in situ temperature $\left(\mathrm{m} \mathrm{d}^{-1}\right), \mathrm{H}_{\mathrm{CO} 2}$ is the solubility coefficient of $\mathrm{CO}_{2}$ in water $\left(\mathrm{mol} \mathrm{m}^{3} \mathrm{~atm}^{-1}\right)$ and is calculated based on the water temperature and the salinity (Weiss 1974), $\mathrm{k}_{600}$ is the gas transfer velocity with a Schmidt number of $600\left(\mathrm{~m} \mathrm{~d}^{-1}\right)$ computed from one out of the seven parameterizations given by Raymond et al. (2012) as recommended by Butman and Raymond (2011) and Raymond et al. (2013), Sc is the Schmidt number of $\mathrm{CO}_{2}$ which is calculated in function of the temperature according to the coefficients of Wanninkhof (Raymond et al. 2012), $\mathrm{V}$ is the water velocity ( $\mathrm{m} \mathrm{s}^{-1}$ ) according to Eq. 6 in Raymond et al. (2012), S is the slope and $\mathrm{Q}$ the discharge $\left(\mathrm{m}^{3} \mathrm{~s}^{-1}\right)$. The Raymond et al. (2012) parameterisation is based on a compilation of $\mathrm{k}_{600}$ values derived from gas tracer release experiments in rivers and streams. Several studies have reported $\mathrm{k}_{600}$ values in tropical rivers derived from floating dome measurements (Alin et al. 2011; de Fátima et al. 2013), although the experimental design of the measurements can strongly influence the derived $\mathrm{k}_{600}$ values (Lorke et al. 2015). Constant values were used for the slope (0.001), the $\mathrm{pCO}_{2}$ of the atmosphere (385 ppm), and the salinity (0), while the other variables were directly measured in the field. Daily fluxes over the whole river stretch were calculated by multiplying $\mathrm{F}_{\mathrm{CO} 2}$ with the river surface area. The daily flux of days with missing $\mathrm{pCO}_{2}$ data was calculated by linear interpolation between the discharge and the daily flux during the respective season and location. The seasonal flux was then again obtained by summing of the daily fluxes.

\section{Internal fluxes}

Similar to the $\mathrm{CO}_{2}$ outgassing flux, the community respiration rates have been estimated based on the measurements in the two sampling sites. In order to do so, the respiration rates were integrated over the total volume of water between the two sites. Because the travel time of the water is approximately five days, the total volume in Garissa was calculated based on the daily discharge of the day of measuring and the discharge of the four preceding days. In Garsen, the day of measurement and the four subsequent days 
were taken into account. The volumes at each site were multiplied with the $\mathrm{CO}_{2}$ equivalent respiration rate of that day and a seasonal estimate of the flux of OC to DIC due to respiration was obtained by summing the daily fluxes.

\section{Results}

Hydrological conditions

The campaign in 2012 covered the first half of the wet season and the discharge in Garissa was characterized by sharp variations with distinct peaks and ranged between 87 and $588 \mathrm{~m}^{3} \mathrm{~s}^{-1}$ (Figs. 3a, 4a, 5a). The peaks were broadened and dampened downstream in Garsen, with discharges ranging from 108 to $268 \mathrm{~m}^{3}$ $\mathrm{s}^{-1}$. During the campaign of 2013, only the falling limb of the wet season hydrograph was sampled, whereby the discharge was decreasing from 768 to $128 \mathrm{~m}^{3} \mathrm{~s}^{-1}$ and from 579 to $136 \mathrm{~m}^{3} \mathrm{~s}^{-1}$ in Garissa and Garsen, respectively (Figs. 3a, 4a, 5a). Consequently, flooding conditions occurred during the first part of the sampling period. This sampling campaign is not entirely representative for the full wet season because the initial peaks and rising limb of the hydrograph
Fig. 3 Time series at two stations in the Tana River (Garissa and Garsen) during three measuring campaigns (2012, 2013, 2014) of: a discharge, $\mathbf{b}$ total suspended matter, c particulate organic carbon concentration, $\mathbf{d}$ mass percent of organic carbon in the total suspended matter (\%OC), and e dissolved organic carbon concentration. The different flow conditions are indicated on top of the panels, whereby the two non-flooded wet periods were combined during the calculations

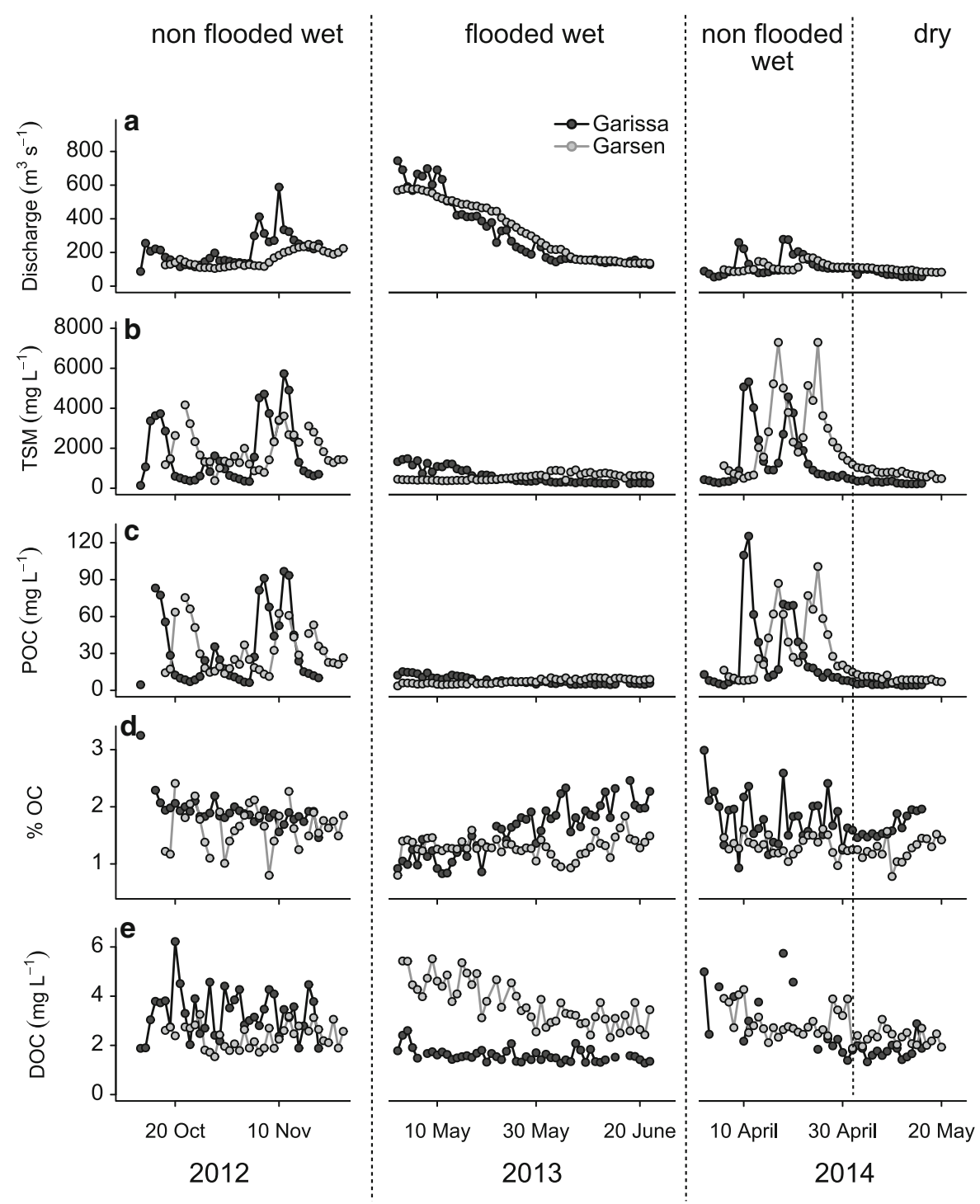


Fig. 4 Time series at two stations in the Tana River (Garissa and Garsen) during three measuring campaigns (2012, 2013, 2014) of: a discharge, b dissolved inorganic carbon concentrations, $\mathbf{c} \mathrm{pCO}_{2}$, d dissolved oxygen saturation levels, and e respiration rates. The different flow conditions are indicated on top of the panels, whereby the two non-flooded wet periods were combined during the calculations
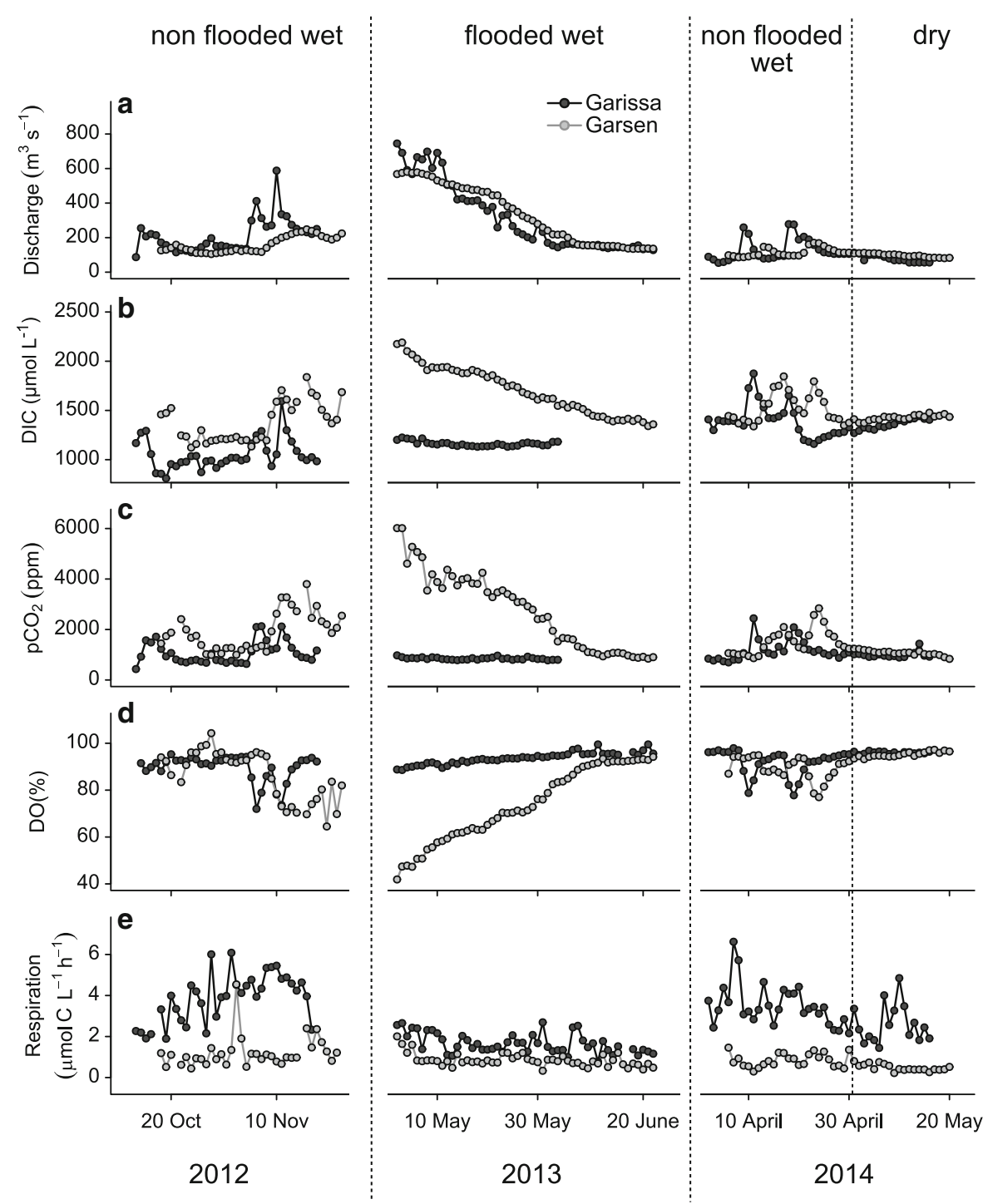

significantly higher than those observed during the dry season with discharge peaks up to $500 \mathrm{~m}^{3} \mathrm{~s}^{-1}$ lasting several days, but no significant flooding occurred in these periods. In 2013, the entire recession phase of a significant flooding event was monitored and the whole monitoring period represents wet flooded conditions $(n=52)$.

In the analysis and discussion of our data, we will focus on the contrasts in $\mathrm{C}$ dynamics among these different river conditions. However, as measurements also reflect the specific conditions in a given year, we will also consider the inter-annual variations (i.e. differences between the different sampling campaigns). 
Fig. 5 Time series at two stations in the Tana River (Garissa and Garsen) during three measuring campaigns (2012, 2013, 2014) of: a discharge, $\mathbf{b} \delta^{13} \mathrm{C}_{\mathrm{POC}}$, c $\delta^{13} \mathrm{C}_{\mathrm{DOC}}$, and $\mathbf{d} \delta^{13} \mathrm{C}_{\mathrm{DIC}}$. The conditions are indicated on top of the panels, whereby the two nonflooded wet periods were combined during the calculations

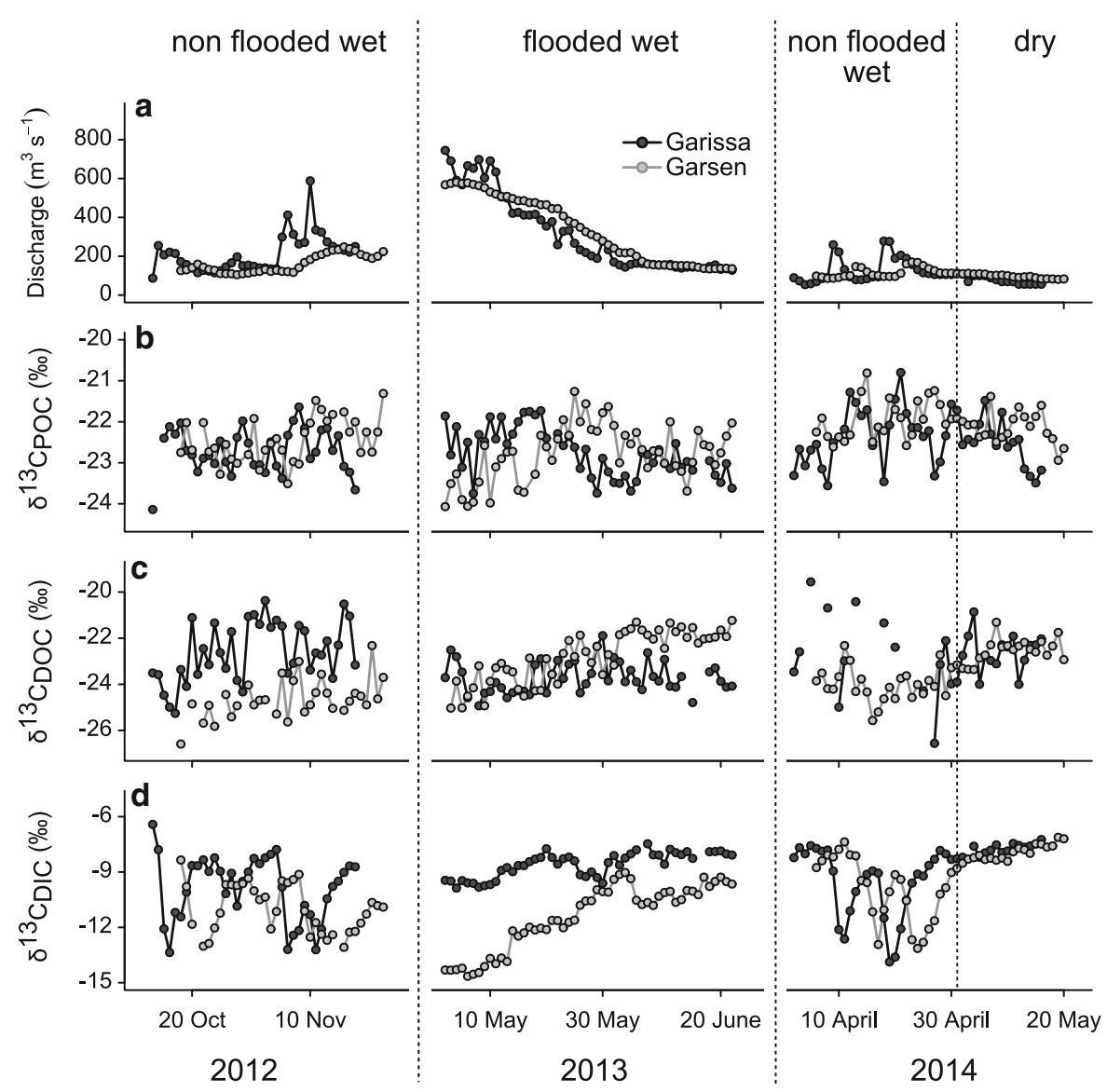

\begin{tabular}{lll}
\hline Hydrological condition & Observation period & \# observations \\
\hline Dry & 2014 campaign: last 17 days & 17 \\
Wet non-flooded & 2012 campaign + 2014 campaign: first 28 days & 65 \\
Wet flooded & 2013 campaign & 52 \\
\hline
\end{tabular}

Table 1 Overview of the subdivision of the dataset over the three hydrological conditions
Total suspended matter and particulate organic carbon

During the non-flooded conditions, the TSM concentration increased with each discharge peak (Fig. 3b), with values up to 5730 and $7300 \mathrm{mg} \mathrm{L}^{-1}$ in Garissa and Garsen, respectively. Comparatively lower TSM concentrations were observed under flooded conditions, with maximum concentrations of $1480 \mathrm{mg} \mathrm{L}^{-1}$ in Garissa and $920 \mathrm{mg} \mathrm{L}^{-1}$ in Garsen. During the dry conditions, TSM concentrations were relatively low, ranging between 215 and $660 \mathrm{mg} \mathrm{L}^{-1}$ in Garissa, while being significantly higher in Garsen (480-1000 $\mathrm{mg} \mathrm{L}^{-1}$ ). 
A similar pattern was visible in the POC concentrations (Fig. 3c). The maximum POC concentration under non-flooded conditions was $125.4 \mathrm{mg} \mathrm{L}^{-1}$ in Garissa and $100.6 \mathrm{mg} \mathrm{L}^{-1}$ in Garsen, in contrast to the flooded conditions with maximum concentrations of 15.2 and $10.5 \mathrm{mg} \mathrm{L}^{-1}$ respectively. Average POC concentrations during dry conditions were $5.3 \mathrm{mg} \mathrm{L}^{-1}$ at Garissa and $9.1 \mathrm{mg} \mathrm{L}^{-1}$ at Garsen.

At each site, the concentrations of TSM and POC were significantly positively correlated with discharge for each of the different flow conditions (Pearson correlation, $\mathrm{p}<0.01, \mathrm{r}=0.34-0.93$ ), except during flooded conditions in Garsen when the relation was negative (Pearson correlation, $\mathrm{p}<0.01, \mathrm{r}=-0.80$ to -0.89 ). The concentration of TSM was significantly different between the two sites during dry and nonflooded wet conditions, while the concentration of POC was significantly different only during dry conditions (paired $t$ test with 5 days time lag, $\mathrm{p}<0.01)$. The concentrations of both TSM and POC under flooded conditions were not significantly different between both sites (paired $t$ test with 5 days time lag, $\mathrm{p}>0.05)$. The three different conditions were at each site significantly different from each other (unpaired $t$ test, $\mathrm{p}<0.01$ ).

The percentage of organic $\mathrm{C}$ in the suspended matter load (\%OC) did not show distinct temporal variations related to discharge, except in 2013 in Garissa, when the \%OC decreased with increasing discharge (Fig. 3d). The average \%OC in Garissa was $1.6 \pm 0.2,1.8 \pm 0.4$ and $1.6 \pm 0.4 \%$ for the three different conditions (dry, non-flooded, flooded) and was, for each of the flow conditions, significantly higher (paired $t$ test, $\mathrm{p}<0.05$ ) than the average \%OC in Garsen, which averaged $1.3 \pm 0.2,1.4 \pm 0.3$ and $1.3 \pm 0.2 \%$, respectively. POC/PN ratios were also fairly constant, with average values of $6.2 \pm 0.3$, $7.8 \pm 1.5$ and $10.0 \pm 0.7$ in Garissa during dry, nonflooded and flooded conditions. Average values in Garsen were $7.3 \pm 0.7,8.3 \pm 1.4$ and $8.5 \pm 0.6$ respectively, and were for all conditions significantly different from those observed in Garissa.

Dissolved organic and inorganic carbon, dissolved oxygen and respiration

During the dry and flooded conditions, DOC concentrations were higher downstream, while during the non-flooded wet conditions, they were higher upstream (Fig. 3e): average DOC concentrations in Garissa were $1.8 \pm 0.4,2.9 \pm 1.1$ and $1.6 \pm 0.3 \mathrm{mg}$ $\mathrm{L}^{-1}$ during dry, non-flooded and flooded conditions, respectively, and $2.3 \pm 0.3, \quad 2.6 \pm 0.6$ and $3.8 \pm 1.1 \mathrm{mg} \mathrm{L}^{-1}$ in Garsen during dry, non-flooded and flooded conditions, respectively. Although these differences in DOC concentration between both sites were statistically significant (paired $t$ test with 5 days time lag, $\mathrm{p}<0.01$ ), they were generally low, except for wet flooded conditions, when the average DOC concentration was more than double in Garsen. Concentrations of DOC were significantly correlated with discharge (Pearson correlation, $\mathrm{p}<0.01$, $\mathrm{r}=0.47-0.69)$ during flooded conditions, while the correlation was weak or absent during dry and nonflooded conditions.

Under non-flooded conditions, the concentration of DIC increased during each discharge peak leading to maximum concentrations up to $1873 \mu \mathrm{mol} \mathrm{L}^{-1}$ (Fig. 4b). During the flooded state, DIC was relatively stable in Garissa with DIC concentrations between

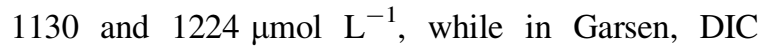
concentrations were much higher at the beginning of the recession phase and declined steadily from 2188 to $1340 \mu \mathrm{mol} \mathrm{L}{ }^{-1}$. The downstream DIC concentrations were during all periods significantly higher in the downstream site than in the upstream site (paired $t$ test with 5 days time lag, $\mathrm{p}<0.01$ ). The DIC was negatively correlated with the $\mathrm{pH}$ during flooded conditions in Garsen (Pearson correlation, $\mathrm{p}<0.01$ ), while no correlation was observed during the other conditions or in Garissa (Pearson correlation, $\mathrm{p}>0.05$ ).

The patterns in $\mathrm{pCO}_{2}$ (Fig. 4c) were similar to those observed in DIC concentrations, with a range of 889-1435, 433-2442 and 778-975 ppm in Garissa during dry, non-flooded and flooded conditions, respectively. Significantly higher values were observed in Garsen during both wet conditions (paired $t$ test with 5 days time lag, $\mathrm{p}<0.01$ ), but not during the dry conditions, with ranges of 863-1169, 836-3800 and 845-6016 ppm during dry, non-flooded and flooded conditions, respectively. The $\mathrm{pCO}_{2}$ was correlated with $\mathrm{pH}$ during wet non-flooded conditions in Garissa (Pearson correlation, $\mathrm{p}<0.05, \mathrm{r}=-0.26$ ) and during both wet conditions in Garsen (Pearson correlation, $\mathrm{p}<0.01, \mathrm{r}=-0.70$ to -0.93 ).

The saturation level of dissolved oxygen in the water (expressed in \%) showed the opposite pattern (Fig. $4 \mathrm{~d}$ ): during the dry period, the oxygen saturation 
varied between 94 and $97 \%$ at both sites. Minimum oxygen saturation levels in Garissa were 72 and $88 \%$ during the non-flooded and flooded wet conditions, while this was 65 and $42 \%$ in Garsen.

Respiration rates were correlated with discharge (Pearson correlation, $\mathrm{p}<0.05, \quad \mathrm{r}=0.35-0.50$ ), except during the dry periods (Fig. 4e). Average respiration rates in Garissa in dry, non-flooded and flooded conditions were 2.6, 3.5 and $1.7 \mu \mathrm{mol} \mathrm{C} \mathrm{L}{ }^{-1}$ $\mathrm{h}^{-1}$, while this was significantly lower (paired $t$ test with 5 days time lag, $\mathrm{p}<0.01$ ) in Garsen with average rates of $0.5,0.9$ and $0.8 \mu \mathrm{mol} \mathrm{C} \mathrm{L} \mathrm{L}^{-1} \mathrm{~h}^{-1}$.

The average of the local calculated $\mathrm{CO}_{2}$ outgassing flux was, during dry conditions, not significantly different in Garissa $\left(3.9 \mathrm{mmol} \mathrm{C} \mathrm{m}^{-2} \mathrm{~h}^{-1}\right)$ in comparison to Garsen $\left(4.3 \mathrm{mmol} \mathrm{C} \mathrm{m}{ }^{-2} \mathrm{~h}^{-1}\right.$ ) (paired $t$ test with 5 days time lag, $\mathrm{p}>0.05$ ). During both wet conditions, the $\mathrm{CO}_{2}$ outgassing flux was higher in Garsen with average values of $9.3 \mathrm{mmol} \mathrm{C} \mathrm{m}{ }^{-2} \mathrm{~h}^{-1}$ during the non-flooded conditions and $19.4 \mathrm{mmol} \mathrm{C}$ $\mathrm{m}^{-2} \mathrm{~h}^{-1}$ during flooding in Garsen, as opposed to 5.2 and $3.8 \mathrm{mmol} \mathrm{C} \mathrm{m} \mathrm{m}^{-2} \mathrm{~h}^{-1}$ in Garissa (paired $t$ test with 5 days time lag, $\mathrm{p}<0.01$ ).

\section{Stable isotope signatures of different $\mathrm{C}$ pools}

No clear temporal patterns were visible in the $\delta^{13} \mathrm{C}_{\mathrm{POC}}$ data (Fig. 5b), and values were not significantly different between the two sites during the dry and flooded conditions. However, they were significantly higher in Garissa during the non-flooded wet periods (paired $t$ test with 5 days time lag, $\mathrm{p}<0.01$ ). Averages over all conditions ranged between $-22.8 \pm 0.6$ and $-22.2 \pm 0.7 \%$. The $\delta^{13} \mathrm{C}_{\mathrm{DOC}}$ was significantly different between both sites during the wet conditions (paired $t$ test with 5 days time lag, $\mathrm{p}<0.01$ ), with lower values in Garsen during the non-flooded state $(-22.6 \pm 1.3$ vs. $-23.9 \pm 1.1 \%)$ and higher values in Garsen during the flooded state $(-23.7 \pm 0.7$ vs. $-22.8 \pm 1.1 \%$, Fig. 5 c).

The DIC became depleted in ${ }^{13} \mathrm{C}$ when the DIC concentration was increasing (Fig. $5 \mathrm{~d}$ ). $\delta^{13} \mathrm{C}_{\text {DIC }}$ ranged at both sites between -8.4 and $-7.2 \%$ during dry conditions. At Garissa, $\delta^{13} \mathrm{C}_{\text {DIC }}$ varied between -13.9 and $-6.4 \%$ during non-flooded conditions and between -9.9 and $-7.5 \%$ during flooding. In Garsen, the range during non-flooded conditions was from -13.1 to $-7.1 \%$, while lower $\delta^{13} \mathrm{C}$ values, between -14.7 and $-9.0 \%$, were measured during flooded conditions.
Major element concentrations

Major elements were compared according to the campaigns (2013 vs. 2014) and not according to the discharge conditions because there were no measurements in 2012.

The concentrations of $\mathrm{Ca}^{2+}$ and $\mathrm{Mg}^{2+}$ were significantly interrelated, and both correlated with TA (Pearson correlation, $\mathrm{p}<0.01, \mathrm{r}=0.46-0.96$ ), but not with discharge, except in Garsen in 2013 (Fig. 6). The concentration of both elements was significantly higher downstream in Garsen compared to Garissa (unpaired $t$ test, $\mathrm{p}<0.01$ ), as the average $\mathrm{Ca}^{2+}$ concentrations over all measurements were $328 \pm 40$ and $407 \pm 41 \mu \mathrm{mol} \mathrm{L}{ }^{-1}$ in Garissa and Garsen, respectively and $141 \pm 16$ and $177 \pm 28 \mu \mathrm{mol} \mathrm{L}{ }^{-1}$, respectively, for $\mathrm{Mg}^{2+}$.

There was a negative correlation between discharge and DSi (Pearson correlation, $\mathrm{p}<0.05$ ), except in Garissa in 2013. Furthermore, there was no correlation between TA and DSi, except in 2013 at Garsen (Pearson correlation, $p<0.05$, Fig. 6). No significant difference was observed between the two sites (unpaired $t$ test, $\mathrm{p}>0.05$ ). The average DSi concentration over all measurements was $259 \pm 21 \mu \mathrm{mol} \mathrm{L}{ }^{-1}$ in Garissa and $260 \pm 15 \mu \mathrm{mol} \mathrm{L}{ }^{-1}$ in Garsen, while the overall range was from 208 to $317 \mu \mathrm{mol} \mathrm{L}^{-1}$.

\section{Fluxes}

The longitudinal, lateral and within-river fluxes were calculated for each of the individual sampling campaigns. When comparing fluxes between sampling campaigns, the different length of the sampling

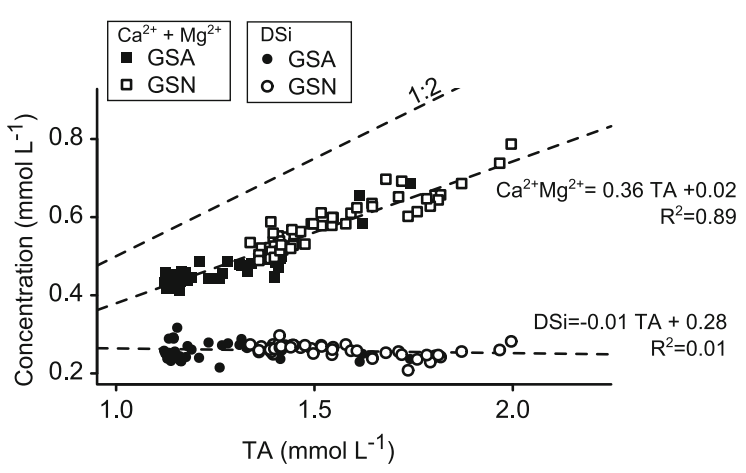

Fig. 6 Concentration of elements $\left(\mathrm{Ca}^{2+}, \mathrm{Mg}^{2+}, \mathrm{DSi}\right)$ related to weathering in function of total alkalinity (TA) obtained in 2013 and 2014 at two stations in the Tana River (Garissa and Garsen) 
Fig. 7 Fluxes of a water,

b sediment and c carbon during the three campaigns $(2012,2013,2014)$ at two sites (GSA Garissa, GSN Garsen) in the Tana River. The numbers in the carbon plot represent the fraction (in \%) of each carbon species relative to the total carbon flux. The number of days over which the samples were taken and fluxes are calculated, are indicated by $n$

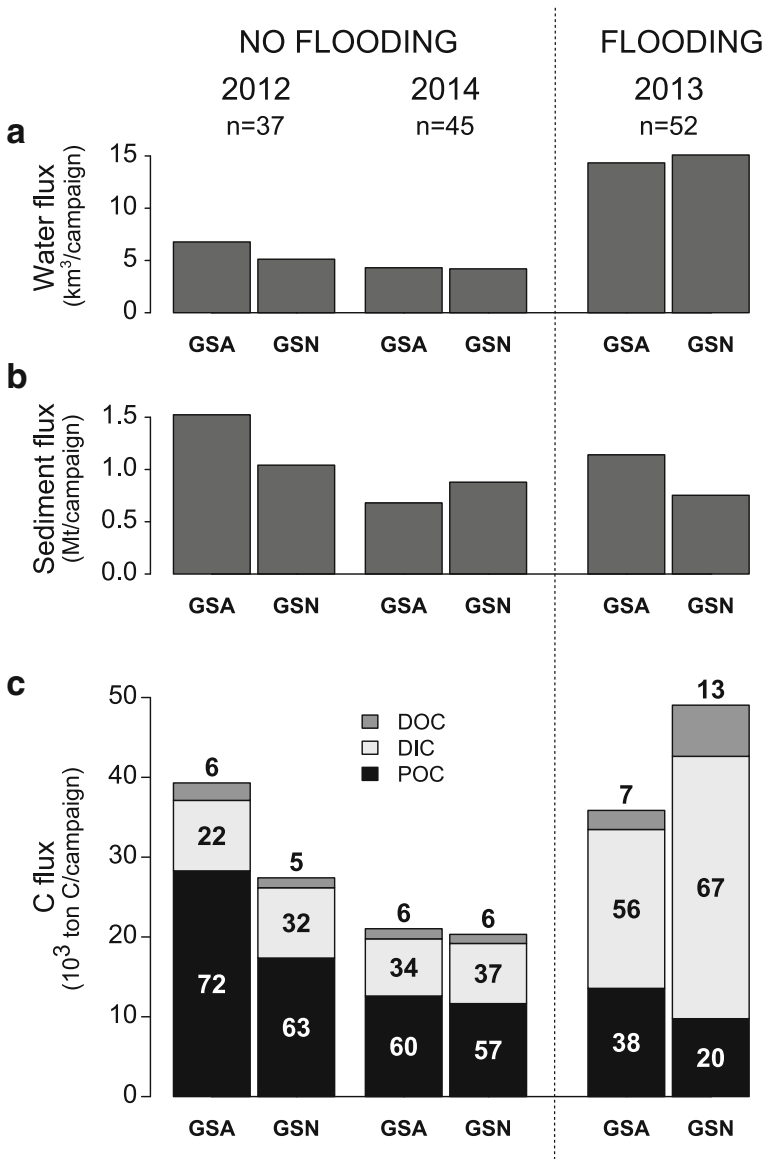

The longitudinal flux of total $\mathrm{C}$ showed also a downstream decreasing pattern during the non-flooded seasons (Fig. 7c; Table 2). This is mainly due to a decrease in POC, which was the dominant fraction (between 57 and $72 \%$ ). DOC was the smallest fraction, ranging between 4 and $6 \%$ of the total $\mathrm{C}$ flux. The difference in DIC fluxes between both stations was very limited during both non-flooded seasons $(0 \%$ in 2012 and $+5 \%$ in 2014). The contrast with the flooded season, both in terms of magnitude and relative contribution of the different pools, was very clear (Fig. 7c; Table 2). During the flooded season of 2013, POC followed the pattern of TSM, which was a relative small and decreasing flux. DIC was the dominant $\mathrm{C}$ pool transported during the flooded season, accounting for 56 and $67 \%$ of the longitudinal total $\mathrm{C}$ flux at Garissa and Garsen, respectively. Longitudinal fluxes of DIC and DOC both increased significantly downstream, by 154 and 64\%, respectively. As a result, the longitudinal total $\mathrm{C}$ flux in Garsen was $36 \%$ higher than upstream in Garissa. 
Table 2 Fluxes of TSM and carbon at both locations (GSA: Garissa, GSN: Garsen) in Tana River during the three measuring campaigns $(2012,2013,2014)$

\begin{tabular}{lccc}
\hline & $\begin{array}{l}\text { GSA 2012 } \\
\mathrm{n}=37 \text { days }\end{array}$ & $\begin{array}{c}\text { GSA 2013 } \\
\mathrm{n}=45 \text { days }\end{array}$ & $\begin{array}{c}\text { GSA 2014 } \\
\mathrm{n}=52 \text { days }\end{array}$ \\
\hline TSM $(\mathrm{Mt})$ & $1.52 \pm 0.03$ & $1.15 \pm 0.02$ & $0.68 \pm 0.01$ \\
POC $\left(10^{3} \mathrm{t}\right)$ & $27.82 \pm 0.45$ & $13.52 \pm 0.25$ & $12.60 \pm 0.40$ \\
DOC $\left(10^{3} \mathrm{t}\right)$ & $2.19 \pm 0.03$ & $2.48 \pm 0.02$ & $1.13 \pm 0.02$ \\
DIC $\left(10^{3} \mathrm{t}\right)$ & $8.83 \pm 0.09$ & $19.81 \pm 0.37$ & $7.16 \pm 0.06$ \\
\hline & GSN 2012 & GSN 2013 & GSN 2014 \\
& $\mathrm{n}=37$ days & $\mathrm{n}=45$ days & $\mathrm{n}=52$ days \\
\hline TSM $(\mathrm{Mt})$ & $1.06 \pm 0.03$ & $0.75 \pm 0.01$ & $0.88 \pm 0.02$ \\
POC $\left(10^{3} \mathrm{t}\right)$ & $18.08 \pm 0.22$ & $9.76 \pm 0.09$ & $11.65 \pm 0.26$ \\
DOC $\left(10^{3} \mathrm{t}\right)$ & $1.24 \pm 0.02$ & $6.30 \pm 0.07$ & $1.14 \pm 0.09$ \\
DIC $\left(10^{3} \mathrm{t}\right)$ & $8.82 \pm 0.10$ & $32.87 \pm 0.31$ & $7.54 \pm 0.09$ \\
\hline
\end{tabular}

$n$ indicates the number of days over which the fluxes are integrated. The error indicates one standard deviation based on the Monte Carlo simulation

Both in 2013 and 2014, the combined longitudinal flux of $\mathrm{Ca}^{2+}$ and $\mathrm{Mg}^{2+}$ increased between Garissa and Garsen, which indicates that carbonate weathering was taking place (Fig. 8a). During the non-flooded season of 2014, the downstream increase in $\left(\mathrm{Ca}^{2+}+\mathrm{Mg}^{2+}\right)$ flux was $15 \mathrm{Mmol}$, which means that a lateral flux of 30 $\mathrm{Mmol}$ of $\mathrm{HCO}_{3}{ }^{-}$(DIC) was transferred from the floodplain or riverbed sediments to the river. This transfer was much larger during the flooded season, as the $\left(\mathrm{Ca}^{2+}+\mathrm{Mg}^{2+}\right)$ flux increased downstream with 324 $\mathrm{Mmol}$, resulting in an increase in $\mathrm{HCO}_{3}{ }^{-}$(DIC) of 649 Mmol. The longitudinal DSi flux increased downstream with $14 \mathrm{Mmol}$ in 2013, while the difference in DSi fluxes was negligible $(0.4 \mathrm{Mmol})$ in 2014.

The within-river flux from OC to DIC due to total aquatic community respiration was much larger when it was calculated using the measurements in Garissa compared to calculations based on the measurements in Garsen (Fig. 8b). The true value is expected to be somewhere in between, depending on the gradient in respiration rates between the sites. The respiration during the flooded season was relatively less important in Garissa compared to the non-flooded seasons as the order of magnitude of the flux over the 52 days flux was similar to the flux in 2012 with only 37 days.

In contrast to respiration, estimated $\mathrm{CO}_{2}$ efflux was larger based on the measurements downstream than upstream in Garissa (Fig. 8c). In Garissa, the

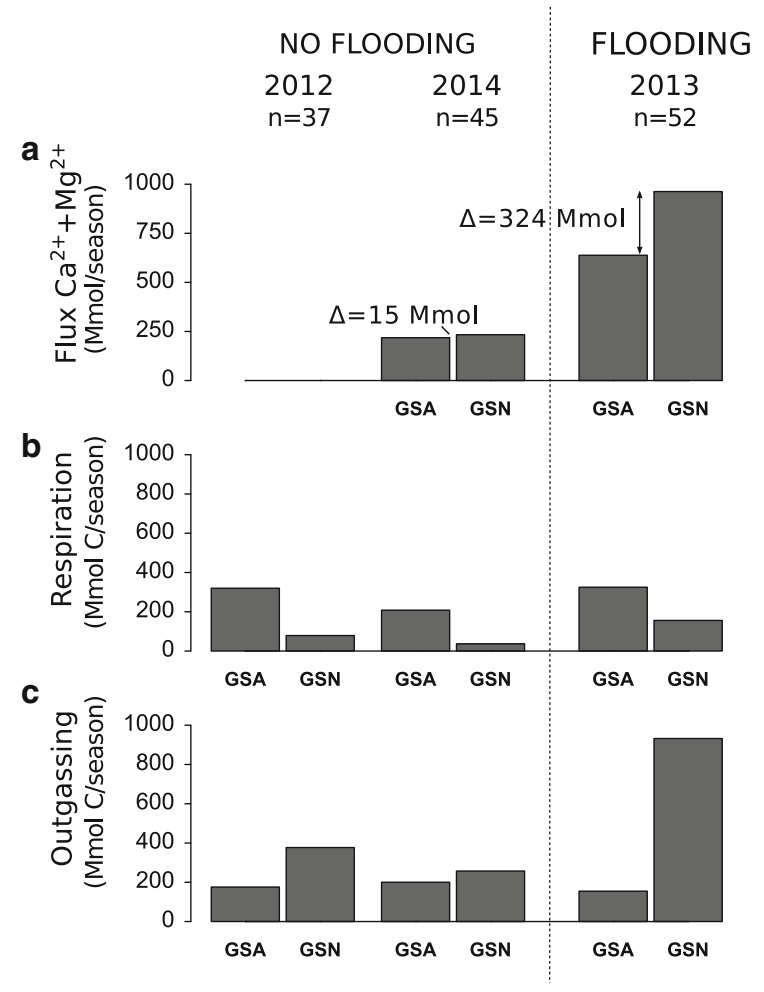

Fig. 8 a Flux of $\mathrm{Ca}^{2+}+\mathrm{Mg}^{2+}$, b flux from OC to DIC due to respiration and $\mathbf{c}$ outgassing over the three measuring campaigns, whereby the latter two are either calculated based on measurements only at Garissa (GSA) or Garsen (GSN) in the Tana River during three measuring campaigns (2012, 2013, 2014). The number of days over which the samples were taken and fluxes are calculated, are indicated by n. Note the same axisscale in (b) and (c) for easy comparison

production of DIC by respiration was always larger than the outgassing of $\mathrm{CO}_{2}$, while in Garsen the outgassing was larger than the production of DIC by respiration. The very large outgassing during the flooded season at Garsen indicates the importance of flooding.

\section{Discussion}

In the discussion, we first focus on the changes in $\mathrm{C}$ concentrations between dry and non-flooded wet conditions. Subsequently, we discuss the contrast between the flooded and non-flooded wet conditions. The insights from those discussions will be used to construct a conceptual framework for the $\mathrm{C}$ dynamics in rivers that will be illustrated by a $\mathrm{C}$ budget for the Tana River for each of the three campaigns. 
Trends in $\mathrm{C}$ dynamics during the dry and nonflooded wet seasons

\section{Particulate organic carbon}

Under non-flooded conditions, the POC concentration increased rapidly in response to a discharge peak. This increase is directly related to the fast mobilisation of sediment with increasing discharge. The relationship between TSM and discharge varied with flow conditions due to a complex interplay between discharge, sediment storage and sediment (re-)mobilisation which is strongly controlled by autogenic processes (Geeraert et al. 2015). The dynamics of POC was similar, due to the strong correlation between the POC concentration and the concentration of TSM.

During earlier monthly monitoring campaigns, a significant correlation was found between $\delta^{13} \mathrm{C}_{\mathrm{POC}}$ and discharge, whereby the POC was more depleted in ${ }^{13} \mathrm{C}$ during the dry seasons (Tamooh et al. 2014). This relationship was not observed during our campaigns, probably because (1) the major variation in $\delta^{13} \mathrm{C}_{\mathrm{POC}}$ in the monthly dataset occurred at low discharges which were less frequent in our dataset, and (2) the larger range in $\delta^{13} \mathrm{C}_{\mathrm{POC}}$ at high discharges in our dataset due to a larger number of observations. In any case, the isotopic signature does not provide information on whether the POC is derived from a different origin throughout the different phases of a wet season.

The upstream POC flux was significantly higher than the flux downstream during the campaigns without flooding, indicating that a considerable amount of POC was stored or mineralised between the two sites (Table 2). To obtain a first estimate of the deposition of POC, we assumed that it was deposited or mobilised to the same extent as the suspended sediment load (i.e. the fraction of POC deposition or mobilisation over the whole season is the same as the fraction of sediment deposition or mobilisation over the whole season). This approach inherently assumes that the contribution of OC to the total TSM load (i.e., \%OC) is constant between the deposited and remobilised sediments. By this method, we estimated that POC deposition was $8.4 \times 10^{3}$ t over the campaign in 2012 and that $3.7 \times 10^{3} \mathrm{t}$ was mobilised during the campaign of 2014 . The relatively large amount of mobilised POC in 2014 is due to the net mobilisation of TSM which resulted, based on our previous assumptions, in a net downstream increase of POC in the river, even though the net POC flux measurements indicated a downstream decrease of POC flux.

The decrease in POC fluxes between the two sites which is not explained by the deposition/mobilisation flux can then be attributed to mineralization, and was estimated at $1.4 \times 10^{3} \mathrm{t}$ in 2012 and $4.6 \times 10^{3} \mathrm{t}$ in 2014. The importance of POC mineralization was apparent from the \%OC data, which were generally lower in the downstream site as the seasonal averages of the \% $\mathrm{OC}$ which were 1.6 and $1.3 \%$ in the dry period and 1.8 and $1.4 \%$ under non-flooded wet conditions for Garissa and Garsen, respectively. Mineralization of POC did not necessarily take place within the river itself, but may also have occurred during the deposition/remobilization cycle of POC in the floodplain or river bed, which may cover a much larger timespan than the period over which measurements were taken.

In other tropical river systems, such as the Amazon, Oubangui, Apure, Caura and Orinoco rivers, a clear negative exponential relationship has been found between \%OC and TSM concentrations that spanned a large range from 0 to ca. $500 \mathrm{mg} \mathrm{L}^{-1}$ (Bouillon et al. 2012; Moreira-Turcq et al. 2013; Mora et al. 2014). This type of relationship was not present in our dataset, probably because all the TSM measurements exceeded $500 \mathrm{mg} \mathrm{L}^{-1}$.

\section{Dissolved organic carbon}

DOC was the least important $\mathrm{C}$ pool in terms of longitudinal fluxes, with a share in the total $\mathrm{C}$ flux of 4-6\% during the non-flooded seasons. However, the importance of the contribution of DOC to the $\mathrm{C}$ budget is not based on its magnitude but on its reactivity. Incubation experiments in 2013 and 2014 have shown that in 14 out of 18 experiments, at least $10 \%$ up to $60 \%$ of the DOC was respired within the first $24-48 \mathrm{~h}$ (Geeraert et al. 2016), suggesting that a significant fraction of DOC is respired and replenished dynamically within the river system, and implying that the magnitude of DOC mineralization cannot be assessed based solely by comparing absolute DOC fluxes upstream and downstream of the study area.

To close the $\mathrm{C}$ budget of the Tana River in wet nonflooded conditions, it is important to identify the source of this reactive DOC. Groundwater and photochemical transformation of OC are reported to be a source of DOC to rivers (Kieber et al. 2006; Bauer and Bianchi 2011). Yet, both sources would result in dilution of the 
concentration during discharge peaks as the water volume increases proportionally much more than the areas of groundwater inflow or water surface. As dilution of DOC was not observed in our datasets, those inputs are unlikely the main source of DOC, unless it is compensated for by other simultaneous mechanisms. Another possible source is the degradation of POC. However, with the increase in POC during discharge peaks, one would assume a proportional increase in DOC concentration, except if other factors limit the DOC production in abundance of POC. Therefore, we have not yet been able to identify the source(s) of the DOC in non-flooded conditions.

\section{Dissolved inorganic carbon}

During high discharge, the Tana River was highly oversaturated in $\mathrm{CO}_{2}$ with respect to the atmospheric equilibrium, with $\mathrm{pCO}_{2}$ values up to $2000 \mathrm{ppm}$ in Garissa and $3800 \mathrm{ppm}$ in Garsen, compared to the atmospheric concentrations around $385 \mathrm{ppm}$. During lower discharge, the water was only slightly oversaturated (700-800 ppm). These $\mathrm{pCO}_{2}$ values were lower than the estimate of median $\mathrm{pCO}_{2}$ for tropical rivers and streams reported by Aufdenkampe et al. (2011), which are 3600 and $4300 \mathrm{ppm}$, respectively. The measured $\mathrm{pCO}_{2}$ values were also lower than in other African rivers with concentrations up to $18,000 \mathrm{ppm}$, and this has been attributed to a relatively low contribution of wetland coverage (Borges et al. 2015b).

Two processes are responsible for the net production of DIC: (1) respiration of organic material and (2) weathering of carbonate rocks (Richey 2004). Indications for the respiration of OM were the simultaneous increase in $\mathrm{pCO}_{2}$ and decrease in dissolved oxygen when DIC concentrations rose during discharge peaks. The stable $\mathrm{C}$ isotopic signature of the DIC during low water levels $(\sim-8 \%)$ is close to the signature measured on the inorganic $\mathrm{C}$ fraction of floodplain soils ( -4 to $-8 \%$, own unpublished data). However, the isotope signature of the DIC became more depleted during discharge peaks, indicating that a larger fraction of DIC was derived from respiration of organic C. The significantly larger flux of $\mathrm{Ca}^{2+}$ and $\mathrm{Mg}^{2+}$ in Garsen was, on the other hand, a strong indicator that carbonate rock weathering occurred between both sites, while no significant increase in DSi was observed implying that silicate rock weathering in the lower Tana River was limited.
The most likely location for the observed weathering to take place is the sediments stored in the Tana floodplain. However, this would imply a lateral flux of weathering products by water from the floodplain to the river. The decrease in water flux between the two sites indicates that the net lateral water flux works in the opposite direction of the weathering flux. Although the inundated areas in 2012 and 2014 were limited, they were at locations near the river such as inner bends of meanders and old river beds as results of meander cut-offs. Water flowing in those areas will interact with the floodplain sediments whereby weathering products may become dissolved in the water. Only part of this water will then return to the river due to evaporation and infiltration losses. A decrease in total discharge downstream can therefore be combined with a net transport of weathering products from the floodplain to the river. Alternatively, the increase in $\mathrm{Ca}^{2+} / \mathrm{Mg}^{2+}$ can also be due to dissolution of particulate inorganic $\mathrm{C}$ (PIC) in the river channel itself.

Changes in the carbon dynamics during overbank flooding

Flooding was found to exert a strong impact on the $\mathrm{C}$ transport fluxes between Garissa and Garsen. While the total $\mathrm{C}$ flux decreased downstream during nonflooded season, there was an increase of $36 \%$ of the total C flux under flooded conditions.

\section{POC}

During periods of overbank flooding, POC concentrations were very low despite the very high discharge. This is related to the reduction of TSM concentrations to which the POC is strongly coupled, and which is explained by a depletion or stabilization of sediment in the river bed (Geeraert et al. 2015). In the time series of TSM, POC and $\delta^{13} \mathrm{C}_{\mathrm{POC}}$, there is a tipping point whereby the values were initially higher in Garissa than in Garsen, but then became lower (Fig. 3). The opposite is true for the \%OC. This pattern suggests the presence of different pools of POC and TSM in the floodplain that are retained during the $1^{\text {st }}$ phase of recession and to some extent released again during a $2^{\text {nd }}$ phase. Again, the first part of this pattern is likely related to autogenic processes, whereby important sedimentation takes places within the Tana river channel during flood recession causing a drop in 
TSM and POC fluxes in the downstream direction. During the last phase of flood recession, net withinchannel deposition of both TSM and POC will decrease as the channel has become adjusted to the lower discharges.

It is less clear what causes the (slight) increase in POC concentration downstream in the $2^{\text {nd }}$ half of the flood recession phase: during this phase, discharges no longer strongly decrease and it may therefore be assumed that net within-channel deposition of TSM and POC is negligible. The (slight) increase in concentration in downstream direction that is observed during this period is consistent with observations under dry conditions: the re-mobilisation of TSM and C may be related to a clear water effect: as incoming concentrations at Garissa are very low, some sediment and POC is mobilised downstream to re-establish equilibrium. It should be kept in mind that concentrations and fluxes during these periods are low compared to the fluxes observed during the non-flooded seasons (which had a lower total discharge and fewer observation days) and the POC was no longer the dominant $\mathrm{C}$ species.

\section{Dissolved C}

The fluxes of the dissolved $\mathrm{C}$ species at Garissa were much larger in 2013 than during the non-flooded seasons of 2012 and 2014. These fluxes further increased strongly downstream, with 64 and $154 \%$ for DIC and DOC, respectively. As the most extensive flooding took place between both sites and such an increase was not observed during non-flooded wet or dry conditions, it is clear that the inundated floodplain acted as a source for DOC and DIC to the river. The importance of the floodplain can also be deduced from the very high $\mathrm{pCO}_{2}$ and TA levels and very low $\mathrm{DO}(\%)$ and $\delta{ }^{13} \mathrm{C}_{\mathrm{DIC}}$ downstream of the floodplain. It has already been demonstrated for other tropical river systems such as the Amazon, Zambezi and Congo rivers, that flooded soils, wetlands and flooded vegetation indeed act as a direct input for dissolved $\mathrm{C}$ and $\mathrm{CO}_{2}$ to the river (Mayorga et al. 2005; Engle et al. 2008; Melack and Engle 2009; Zurbrügg et al. 2013; Abril et al. 2014; Borges et al. 2015a, b; Teodoru et al. 2015).

The different mechanisms between non-flooded and flooded conditions impede the calculation of average annual $\mathrm{C}$ fluxes as the flooding frequency has to be taken into account. Furthermore, the exchange with the floodplain will depend on the flooding extent. To assess those fluxes properly, hydrological models of the floodplain are needed to complement the understanding of the $\mathrm{C}$ dynamics in the inundated floodplain (Rudorff et al. 2014a, b).

Application of the conceptual framework

The calculated fluxes can be incorporated in our conceptual framework after making some further simplifications (Fig. 9):

(1) Within-river primary production was not taken into account. Although primary production rates at the water surface of the lower Tana were on average $1.1 \mu \mathrm{mol} \mathrm{L} \mathrm{L}^{-1} \mathrm{~h}^{-1}$ during a wet season campaign (Tamooh 2013), photosynthesis over the whole water column is very small due to the high turbidity of the water in the Tana. If we assume (as a rough estimate) an average light penetration depth of $20 \mathrm{~cm}$ and a surface area of $38.5 \mathrm{~km}^{2}$, the total C fixation rate due to photosynthesis is estimated at 7.5, 10.6 and 9.1 Mmol over the entire duration of the 2012, 2013 and 2014 campaigns respectively. This is negligible compared to the other $\mathrm{C}$ fluxes and rates considered.

(2) We considered only carbonate weathering and no silicate weathering because the concentrations of $\mathrm{Ca}^{2+}$ and $\mathrm{Mg}^{2+}$ varied significantly with DIC while the flux of DSi showed only minor variations between Garissa and Garsen (an increase with only $14 \mathrm{Mmol}$ in 2013 and a decrease by $-0.4 \mathrm{Mmol}$ in 2014), and the DSi concentration was not correlated with discharge or DIC.

(3) The degradation of POC (flux 6) and mineralization of DOC (flux 7) were simplified to reduce the number of tuning parameters. We assumed that the degraded POC (flux 6) was completely transferred to the DOC pool, which is equivalent to a distribution coefficient (DIC:DOC) of 0:1. The BGE was assumed to be 0 , so the mineralised DOC is completely transformed to DIC. By making these simplifications, the magnitude of the flux due to respiration of POC can be estimated based on a flux balance of the POC pool, and the measured flux due to respiration, which included both respiration of DOC and POC, can be represented by a single respiration flux from DOC to DIC. 
Fig. 9 Application of the conceptual framework to the calculated carbon fluxes for each of the three campaigns $(2012,2013,2014)$ in the Tana River. The width of the lines, proportional to the magnitude of the fluxes, are consistent within one year, but not between the different years
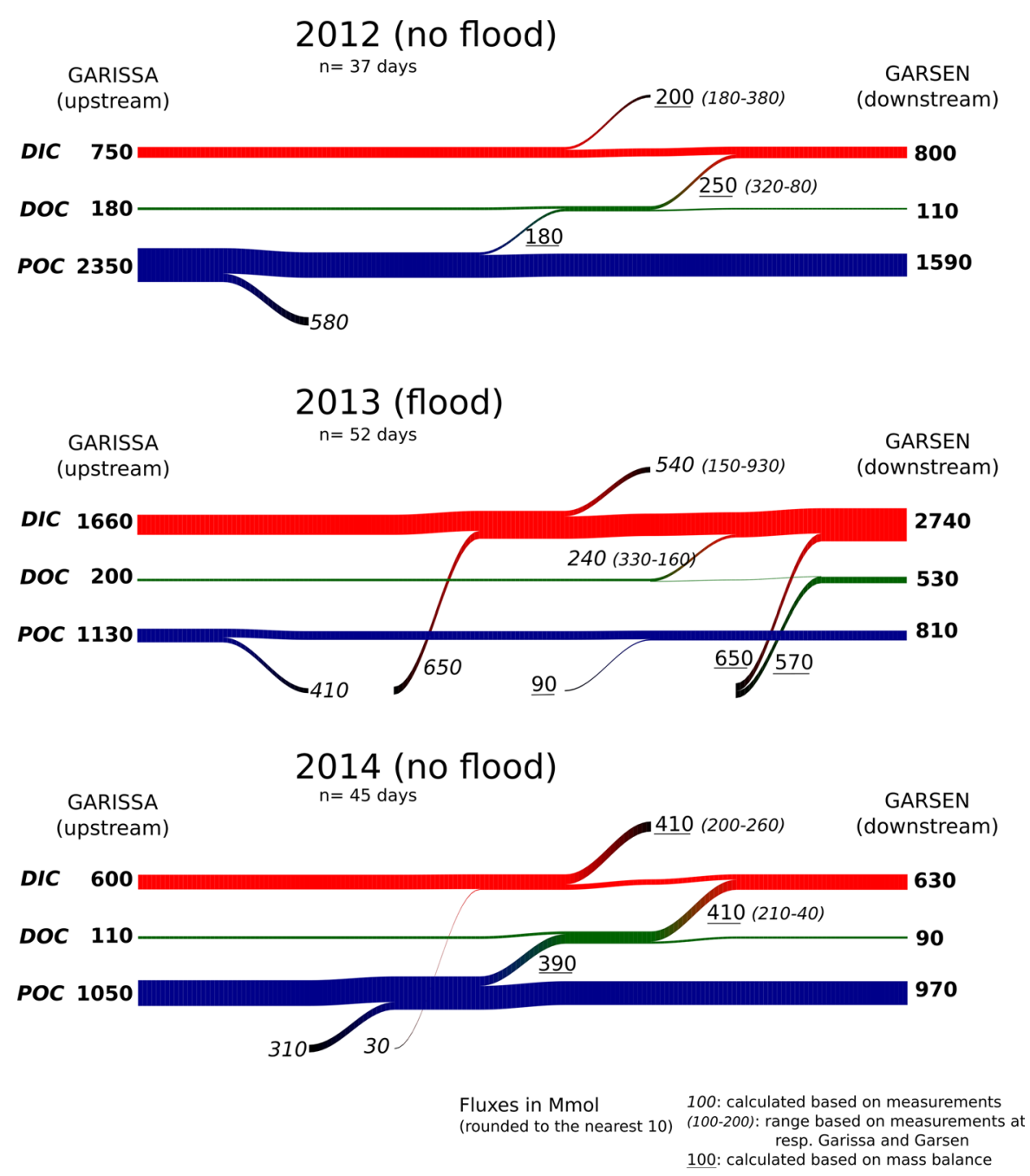

With these simplifications, we first calculated the longitudinal $\mathrm{C}$ fluxes at the inflow and outflow stations of the river stretch (Garissa and Garsen, Table 2), as well as the magnitude of POC exchange with the floodplain and the weathering-derived DIC flux (Fig. 9). For the datasets collected in 2012 and 2014, the other components of our framework could then be calculated based on mass balance considerations $\left(F_{\text {in }}=F_{\text {out }}+F_{\text {lat }}+F_{\text {int }}\right)$. For the 2013 dataset, the calculation based on mass balance was not possible because there was a negative balance for the POC due to floodplain deposition and an additional net input of DIC and DOC from the floodplain. In this case, we resorted to calculating the magnitude of respiration and $\mathrm{CO}_{2}$ evasion over the entire river section as the average values of those obtained for Garissa and
Garsen, and calculated the DIC and DOC inputs from the floodplain as the closing term for the overall $\mathrm{C}$ balance.

The correct estimation of exchange of POC with the floodplain is important to close the $\mathrm{C}$ budgets properly. In 2012, the net deposition could be estimated relatively accurately from our data, as the mineralisation of DOC and the flux to the atmosphere based on the mass balance fall within the range of the calculated values based on the measurements (Fig. 9). Even though there were no direct measurements of the carbonate rock weathering, the mass balance estimates would still be within range, if the weathering flux would have been in the same order of magnitude as in 2014. The deposition of POC during the flooded season in 2013, estimated based on the fraction of 
TSM deposited, turned out to be an overestimation: the measured POC flux at Garsen was $90 \mathrm{Mmol}$ higher than the model estimate. This resulted in a negative estimate of the amount of mineralised POC (equal to the difference between the upstream influx and the sum of the deposited POC and the downstream outflux), which is quite unrealistic, and an additional flux had to be drawn from the floodplain to close the budget (Fig. 9). In 2014, a closed C budget could be established despite the relatively large POC flux from the floodplain to the river, but the estimates of the total respiration and outgassing flux derived by closing the mass balance were more than double of the estimates based on the measurements (Fig. 9).

The flux from OC to DIC and the outgassing during the non-flooded seasons were relatively well balanced when estimated by both methods (mass balance and direct measurements). This balance over the whole study area can hide local imbalances, as is clear from the range of estimates, whereby the DIC production by respiration in Garissa is much larger than the outgassing, while the reverse is true at Garsen. This pattern indicates that there is a strong longitudinal gradient in the ratio between them. In Garissa, the outgassing can for $100 \%$ be supported by local respiration, while there is still excess $\mathrm{CO}_{2}$ that will be transported downstream. At Garsen, the $\mathrm{CO}_{2}$ evasion is only to a certain extent supported by local respiration, while the remaining $\mathrm{CO}_{2}$ will have been produced more upstream in the river. Besides the in situ respiration, additional lateral fluxes of DIC have been reported as an important source for the riverine $\mathrm{CO}_{2}$ flux to the atmosphere (Abril et al. 2014; Borges et al. 2015b; Hotchkiss et al. 2015; Tweed et al. 2015). To assess the importance of these lateral fluxes in the Tana River, additional research about the ground water flows would be required.

During the flooded season in 2013, outgassing is almost double of the respiration. This increased outgassing is fuelled by DIC fluxes coming from the floodplain. Half of the floodplain flux could be associated with weathering processes $(650 \mathrm{Mmol})$, based on the strong increase in $\mathrm{Ca}^{2+}$ and $\mathrm{Mg}^{2+}$, while the other half was likely due to respiration within the floodplain waters $(650 \mathrm{Mmol})$ which returned to the main river (Fig. 9). Most of the $\mathrm{CO}_{2}$ from these floodplain fluxes was still in the river at Garsen and was further transported to the delta and the ocean. This could lead to a temporal acidification of those waters as a result of the flooding.

The difference in dynamics between non-flooded and flooded conditions presents challenges for modelling $\mathrm{C}$ dynamics in such river systems. The first challenge is the need for data covering not only the full spectrum of the hydrograph, but ideally also including process and flux rates within the inundated floodplains. This is complicated by the relatively low frequency and low predictability of the flooding events. The second challenge is the probable influence of the magnitude of the flooding and the time span of the flooding, especially because the floodplain can still be flooded and partially connected to the river, even when the discharge in the river has decreased. Assessing the impact of these processes in detail requires the coupling of a detailed $\mathrm{C}$ dynamics model to a hydrological model.

\section{Conclusions}

Our study, with monitoring of the TSM and C fluxes at a daily resolution, shows that $\mathrm{C}$ dynamics in the Tana River system changes fundamentally between nonflooded and flooded wet conditions. It is therefore imperative to consider these two situations separately when long term $\mathrm{C}$ budgets are calculated. POC was the dominant species during the non-flooded seasons and a downstream decrease in total $\mathrm{C}$ flux was observed, while DIC was the dominant species during the flooded conditions along with a downstream increase in total $\mathrm{C}$. The difference in $\mathrm{C}$ dynamics between flooded and non-flooded conditions illustrates the important role of the floodplain that may not only retain POC, but may also deliver significant fluxes of DIC to the river system, both as a result of weathering processes and floodplain respiration.

The differentiation between hydrological conditions is especially important when calculating annual $\mathrm{C}$ fluxes for river systems with alterations between dry seasons and wet seasons which occasionally lead to extensive flooding, as the occurrence of a strong wet season influences both the magnitude of the $\mathrm{C}$ fluxes as well as $\mathrm{C}$ speciation. Therefore, we proposed a framework to identify the main processes regulating $\mathrm{C}$ transport in the river system. The application of this framework to our dataset revealed that a proper quantification of the amount of POC which is 
deposited or mobilised is a key factor for the establishment of a realistic $\mathrm{C}$ budget. Indeed, rivers such as the Tana River do not only process significant amounts of $\mathrm{C}$, but may also store and remobilize $\mathrm{C}$. Notwithstanding longitudinal variations, respiration and outgassing of the Tana River were well balanced during the non-flooded seasons. During the flooded season, on the other hand, outgassing was fuelled by inputs from the floodplains and a large amount of DIC was further transported towards the delta. A deeper understanding of the change in dynamics under different hydrological conditions is required in order to construct biogeochemical models and to fully assess the impacts of environmental changes.

Acknowledgements Funding was provided by the KU Leuven Special Research Fund, the Research Foundation Flanders (FWO-Vlaanderen, Project G024012N), and an ERC Starting Grant (240002, AFRIVAL). We are grateful to the Kenya Wildlife Service (KWS) for assistance during field experiments and to Z. Kelemen for help with stable isotope analyses. AVB is a senior research associate at the Fonds National de la Recherche Scientifique (FNRS).

\section{References}

Abril G, Martinez J-M, Artigas LF, Moreira-Turcq P, Benedetti MF, Vidal L, Meziane T, Kim J-H, Bernardes MC et al (2014) Amazon River carbon dioxide outgassing fuelled by wetlands. Nature 505:395-398. doi:10.1038/nature12797

Abril G, Bouillon S, Darchambeau F, Teodoru CR, Marwick TR, Tamooh F, Omengo FO, Geeraert N, Deirmendjian L et al (2015) Technical note: large overestimation of $\mathrm{pCO}_{2}$ calculated from $\mathrm{pH}$ and alkalinity in acidic, organic-rich freshwaters. Biogeosciences 12:67-78

Alin SR, Rasera MFFL, Salimon CI, Richey JE, Holtgrieve GW, Krusche AV, Snidvongs A (2011) Physical controls on carbon dioxide transfer velocity and flux in low-gradient river systems and implications for regional carbon budgets. J Geophys Res 116:G01009. doi:10.1029/2010JG001398

Amado AM, Meirelles-Pereira F, Vidal LO, Sarmento H, Suhett AL, Farjalla VF, Cotner JB, Roland F (2013) Tropical freshwater ecosystems have lower bacterial growth efficiency than temperate ones. Front Microbiol. doi:10.3389/ fmicb.2013.00167

Aufdenkampe AK, Mayorga E, Raymond PA, Melack JM, Doney SC, Alin SR, Aalto RE, Yoo K (2011) Riverine coupling of biogeochemical cycles between land, oceans, and atmosphere. Front Ecol Environ 9:53-60. doi:10.1890/ 100014

Battin TJ, Luyssaert S, Kaplan LA, Aufdenkampe AK, Richter A, Tranvik LJ (2009) The boundless carbon cycle. Nat Geosci 2:598-600. doi:10.1038/ngeo618

Bauer JE, Bianchi TS (2011) Dissolved organic carbon cycling and transformation. In: Wolanski E, McLusky D (eds)
Treatise on estuarine and coastal science, vol 5. Waltham: Academic Press, pp 7-68. doi: 10.1016/B978-0-12374711-2.00502-7

Berggren M, Lapierre J-F, del Giorgio PA (2012) Magnitude and regulation of bacterioplankton respiratory quotient across freshwater environmental gradients. ISME J 6:984-993. doi:10.1038/ismej.2011.157

Borges AV, Abril G, Darchambeau F, Teodoru CR, Deborde J, Vidal LO, Lambert T, Bouillon S (2015a) Divergent biophysical controls of aquatic $\mathrm{CO}_{2}$ and $\mathrm{CH}_{4}$ in the world's two largest rivers. Sci Rep 5:15614. doi:10.1038/ srep 15614

Borges AV, Darchambeau F, Teodoru CR, Marwick TR, Tamooh F, Geeraert N, Omengo FO, Guérin F, Lambert T et al (2015b) Globally significant greenhouse-gas emissions from African inland waters. Nat Geosci 8:637-642. doi:10.1038/ngeo2486

Bouillon S, Abril G, Borges AV, Dehairs F, Govers G, Hughes HJ, Merckx R, Meysman FJR (2009) Distribution, origin and cycling of carbon in the Tana River (Kenya): a dry season basin-scale survey from headwaters to the delta. Biogeosciences 6:2475-2493

Bouillon S, Yambélé A, Spencer RGM, Gillikin DP, Hernes PJ, Six J, Merckx R, Borges AV (2012) Organic matter sources, fluxes and greenhouse gas exchange in the Oubangui River (Congo River basin). Biogeosciences 9:2045-2062. doi:10.5194/bg-9-2045-2012

Brunet F, Dubois K, Veizer J, Ndondo GN, Ngoupayou JN, Boeglin J-L, Probst J-L (2009) Terrestrial and fluvial carbon fluxes in a tropical watershed: Nyong basin, Cameroon. Chem Geol 265:563-572

Butman D, Raymond PA (2011) Significant efflux of carbon dioxide from streams and rivers in the United States. Nat Geosci 4:839-842

Ciais P, Sabine C, Bala G, Bopp L, Brovkin V, Canadell J, Chhabra A, DeFries R, Galloway J, et al. (2014) Carbon and other biogeochemical cycles. In: Climate change 2013: the physical science basis. Contribution of working group I to the fifth assessment report of the intergovernmental panel on climate change. Cambridge University Press, Cambridge, pp 465-570

Cole JJ, Prairie YT, Caraco NF, McDowell WH, Tranvik LJ, Striegl RG, Duarte CM, Kortelainen P, Downing JA et al (2007) Plumbing the global carbon cycle: integrating inland waters into the terrestrial carbon budget. Ecosystems 10:172-185. doi:10.1007/s 10021-006-9013-8

Coynel A, Seyler P, Etcheber H, Meybeck M, Orange D (2005) Spatial and seasonal dynamics of total suspended sediment and organic carbon species in the Congo River. Global Biogeochem Cycles 19:GB4019. doi: 10.1029/ 2004GB002335

de Fátima M, Rasera M, Krusche AV, Richey JE, Ballester MVR, Victória RL (2013) Spatial and temporal variability of $\mathrm{pCO}_{2}$ and $\mathrm{CO}_{2}$ efflux in seven Amazonian Rivers. Biogeochemistry 116:241-259

Denman KL, Brasseur G, Chidthaisong A, Ciais P, Cox PM, Dickinson RE, Hauglustaine D, Heinze C, Holland E, et al. (2007) Couplings between changes in the climate system and biogeochemistry. In: Solomon S, Qin D, Manning M, Chen Z, Marquis M, Averyt KB, Tignor M, Miller HL (eds) Climate change 2007: the physical science basis. 
Contribution of working group I to the fourth assessment report of the intergovernmental panel on climate change. Cambridge University Press, Cambridge

DHV (1986) Tana river morphology studies, final report: volume 1 main report. Delft Hydraulics Laboratory, Delft

Ellis EE, Richey JE, Aufdenkampe AK, Krusche AV, Quay PD, Salimon C, da Cunha HB (2012) Factors controlling watercolumn respiration in rivers of the central and southwestern Amazon Basin. Limnol Oceanogr 57:527-540. doi:10. 4319/1o.2012.57.2.0527

Engle DL, Melack JM, Doyle RD, Fisher TR (2008) High rates of net primary production and turnover of floating grasses on the Amazon floodplain: implications for aquatic respiration and regional $\mathrm{CO}_{2}$ flux. Glob Chang Biol 14:369-381

Garrels RM, Mackenzie FT (1971) Evolution of sedimentary rocks. Norton, New York, p 397

Geeraert N, Omengo FO, Tamooh F, Paron P, Bouillon S, Govers G (2015) Sediment yield of the lower Tana River, Kenya, is insensitive to dam construction: sediment mobilization processes in a semi-arid tropical river system. Earth Surf Proc Land 40:1827-1838. doi:10.1002/ esp. 3763

Geeraert N, Omengo F, Govers G, Bouillon S (2016) Dissolved organic carbon lability and stable isotope shifts during microbial decomposition in a tropical river system. Biogeosci 13:517-525. doi:10.5194/bg-13-517-2016

Gillikin DP, Bouillon S (2007) Letter to the editor. Rapid CommunMass Sp 21:1475-1478. doi:10.1002/rcm

Hotchkiss E, Hall R Jr, Sponseller R, Butman D, Klaminder J, Laudon H, Rosvall M, Karlsson J (2015) Sources of and processes controlling $\mathrm{CO}_{2}$ emissions change with the size of streams and rivers. Nat Geosci 8:696-699. doi:10.1038/ NGEO2507

Kieber RJ, Whitehead RF, Skrabal SA (2006) Photochemical production of dissolved organic carbon from resuspended sediments. Limnol Oceanogr 51:2187-2195

Koné Y, Abril G, Delille B, Borges A (2010) Seasonal variability of methane in the rivers and lagoons of Ivory Coast (West Africa). Biogeochemistry 100:21-37

Lambert T, Darchambeau F, Bouillon S, Alhou B, Mbega J-D, Teodoru CR, Nyoni FC, Massicotte P, Borges AV (2015) Landscape control on the spatial and temporal variability of chromophoric dissolved organic matter and dissolved organic carbon in large African rivers. Ecosystems 18:1224-1239. doi:10.1007/s10021-015-9894-5

Lauerwald R, Laruelle GG, Hartmann J, Ciais P, Regnier PA (2015) Spatial patterns in $\mathrm{CO}_{2}$ evasion from the global river network. Global Biogeochem Cycles 29:534-554. doi:10.1002/2014GB004941

Leauthaud C, Belaud G, Duvail S, Moussa R, Grünberger O, Albergel J (2013) Characterizing floods in the poorly gauged wetlands of the Tana River Delta, Kenya, using a water balance model and satellite data. Hydrol Earth Sys Sci 17(8):3059-3075. doi:10.5194/hess-17-3059-2013

Lesack LFW, Hecky RE, Melack JM (1984) Transport of carbon, nitrogen, phosphorus, and major solutes in the Gambia River, West Africa. Limnol Oceanogr 29(4):816-830

Lewis E, Wallace D (1998) Program developed for $\mathrm{CO}_{2}$ system calculations (Carbon Dioxide Information Analysis Center, Oak Ridge National Laboratory, US Dept. of Energy, Oak Ridge, TN). ORNL/CDIAC-105
Liu Z, Dreybrodt W, Liu H (2011) Atmospheric $\mathrm{CO}_{2}$ sink: silicate weathering or carbonate weathering? Appl Geochem 26:S292-S294

Lorke A, Bodmer P, Noss C, Alshboul Z, Koschorreck M, Somlai-Haase C, Bastviken D, Flury S, McGinnis DF, Maeck A, Müller D, Premke K (2015) Technical note: drifting versus anchored flux chambers for measuring greenhouse gas emissions from running waters. Biogeosciences 12:7013-7024

Marwick TR (2014) Biogeochemistry of inland waters: insights from (sub)tropical river basins of Africa. Dissertation, University of Leuven

Marwick TR, Borges AV, Van Acker K, Darchambeau F, Bouillon S (2014) Disproportionate contribution of riparian inputs to organic carbon pools in freshwater systems. Ecosystems 17:974-989

Mayorga E, Aufdenkampe AK, Masiello CA, Krusche AV, Hedges JI, Quay PD, Richey JE, Brown TA (2005) Young organic matter as a source of carbon dioxide outgassing from Amazonian rivers. Nature 436:538-541. doi:10.1038/ nature 03880

Melack JM, Engle D (2009) An organic carbon budget for an Amazon floodplain lake. Verh Internat Verein Limnol 30:1179-1182

Melack JM, Forsberg BR (2001) The biogeochemistry of the Amazon Basin and its role in a changing world. In: McClain M, Victoria R, Richey JE (eds) Oxford University Press, Oxford. pp 235-276

Melack JM, Hess LL, Gastil M, Forsberg BR, Hamiltons SK, Lima IBT, Novo EMLM (2004) Regionalization of methane emissions in the Amazon Basin with microwave remote sensing. Glob Chang Biol 10:530-544. doi:10. 1111/j.1529-8817.2003.00763.x

Millero FJ (1979) The thermodynamics of the carbonate system in seawater. Geochemica et Cosmochemica Acta 43:1651-1661

Mora A, Laraque A, Moreira-Turch P, Alfonso JA (2014) Temporal variation and fluxes of dissolved and particulate organic carbon in the Apure, Caura and Orinoco rivers, Venezuela. J S Am Earth Sci 54:47-56

Moreira-Turcq P, Bonnet M-P, Amorim M, Bernardes M, Lagane C, Maurice L, Perez M, Seyler P (2013) Seasonal variability in concentration, composition, age, and fluxes of particulate organic carbon exchanged between the floodplain and Amazon River. Global Biogeochem Cycles 27:119-130

Omengo FO, Alleman T, Geeraert N, Bouillon S, Govers G (2016) Sediment deposition patterns in a tropical floodplain, Tana River, Kenya. Catena 143:57-69. doi:10.1016/ j.catena.2016.03.024

Pettit N, Bayliss P, Davies P, Hamilton S, Warfe D, Bunn S, Douglas M (2011) Seasonal contrasts in carbon resources and ecological processes on a tropical floodplain. Freshwater Biol 56(6):1047-1064

Raymond PA, Zappa CJ, Butman D, Bott TL, Potter J, Mulholland P, Laursen AE, McDowell WH, Newbold D (2012) Scaling the gas transfer velocity and hydraulic geometry in streams and small rivers. Limnol Oceanogr 2:41-53

Raymond PA, Hartmann J, Lauerwald R, Sobek S, McDonald C, Hoover M, Butman D, Striegl R, Mayorga E et al (2013) Global carbon dioxide emissions from inland waters. Nature 503:355-359. doi:10.1038/nature12760 
Regnier P, Friedlingstein P, Ciais P, Mackenzie FT, Gruber N, Janssens IA, Laruelle GG, Lauerwald R, Luyssaert S et al (2013) Anthropogenic perturbation of the carbon fluxes from land to ocean. Nat Geosci 6:597-607. doi:10.1038/ ngeo 1830

Richardson DC, Newbold JD, Aufdenkampe AK, Taylor PG, Kaplan LA (2013) Measuring heterotrophic respiration rates of suspended particulate organic carbon from stream ecosystems. Limnol Oceanogr 11:247-261. doi:10.4319/ lom.2013.11.247

Richey J (2004) Pathways of atmospheric $\mathrm{CO}_{2}$ through fluvial systems. In: Field CB, Raupach MR (eds) The global carbon cycle: integrating humans, climate and the natural world. Island Press, Washington, D.C., pp 329-340

Richey J, Melack J, Aufdenkampe A, Ballester V, Hess L (2002) Outgassing from Amazonian rivers and wetlands as a large tropical source of atmospheric $\mathrm{CO}_{2}$. Nature 416:617-620

Rudorff CM, Melack JM, Bates PD (2014a) Flooding dynamics on the lower Amazon floodplain: 2. Seasonal and interannual hydrological variability. Water Resour Res 50:635-649. doi:10.1002/2013WR014714

Rudorff CM, Melack JM, Bates PD (2014b) Flooding dynamics on the lower Amazon floodplain: 1. Hydraulic controls on water elevation, inundation extent, and river-floodplain discharge. Water Resour Res 50 doi:10.1002/ 2013WR014091

Spencer RG, Hernes PJ, Aufdenkampe AK, Baker A, Gulliver P, Stubbins A, Aiken GR, Dyda RY, Butler KD et al (2012) An initial investigation into the organic matter biogeochemistry of the Congo River. Geochim Cosmochim Acta 84:614-627

Syvitski JPM, Cohen S, Kettner AJ, Brakenridge GR (2014) How important and different are tropical rivers? An overview. Geomorphology 227:5-17. doi:10.1016/j.geomorph. 2014.02.029

Tamooh F (2013) Carbon cycling from a catchment perspective: an integrated approach to terrestrial-aquatic linkages in the Tana River basin, Kenya. Dissertation, University of Leuven

Tamooh F, Van den Meersche K, Meysman F, Marwick TR, Borges AV, Merckx R, Dehairs F, Schmidt S, Nyunja J et al (2012) Distribution and origin of suspended matter and organic carbon pools in the Tana River Basin, Kenya. Biogeosciences 9(8):2905-2920. doi:10.5194/bg-9-29052012

Tamooh F, Borges AV, Meysman F, Van den Meersche K, Dehairs F, Merckx R, Bouillon S (2013) Dynamics of dissolved inorganic carbon and aquatic metabolism in the Tana River Basin, Kenya. Biogeosciences 10:6911-6928. doi:10.5194/bgd-10-6911-2013

Tamooh F, Meysman FJR, Borges AV, Marwick TR, Van den Meersche K, Dehairs F, Merckx R, Bouillon S (2014) Sediment and carbon fluxes along a longitudinal gradient in the lower Tana River (Kenya). J Geophys Res Biogeosci 119:1340-1353. doi:10.1002/2013JG002358

Teodoru CR, Del Giorgio PA, Prairie YT, Camire M (2009) Patterns in $\mathrm{pCO}_{2}$ in boreal streams and rivers of northern Quebec, Canada. Global Biogeochem Cycles 23:GB2012. doi:10.1029/2008GB003404

Teodoru CR, Nyoni F, Borges A, Darchambeau F, Nyambe I, Bouillon S (2015) Dynamics of greenhouse gases $\left(\mathrm{CO}_{2}\right.$, $\mathrm{CH}_{4}, \mathrm{~N}_{2} \mathrm{O}$ ) along the Zambezi River and major tributaries, and their importance in the riverine carbon budget. Biogeosciences 12:2431-2453

Tranvik LJ, Downing JA, Cotner JB, Loiselle SA, Striegl RG, Ballatore TJ, Dillon P, Finlay K, Fortino K et al (2009) Lakes and reservoirs as regulators of carbon cycling and climate. Limnol Oceanogr 54:2298-2314

Tweed S, Leblanc M, Bass A, Harrington GA, Munksgaard N, Bird MI (2015) Leaky savannas: the significance of lateral carbon fluxes in the seasonal tropics. Hydrol Process. doi:10.1002/hyp. 10640

Wang ZA, Bienvenu DJ, Mann PJ, Hoering KA, Poulsen JR, Spencer RGM, Holmes RM (2013) Inorganic carbon speciation and fluxes in the Congo River. Geophys Res Lett 40:511-516. doi: 10.1002/grl.50160

Ward ND, Keil RG, Medeiros PM, Brito DC, Cunha AC, Dittmar T, Yager PL, Krusche AV, Richey JE (2013) Degradation of terrestrially derived macromolecules in the Amazon River. Nat Geosci 6(7):530-533. doi:10.1038/ ngeo1817

Wehrli B (2013) Conduits of the carbon cycle. Nature 503:9-10

Weiss RF (1974) Carbon dioxide in water and seawater: the solubility of a non-ideal gas. Marine Chem 2:203-215

World Bank Climate Variability Tool (2015) http://iridl.ldeo. columbia.edu/maproom/Global/World_Bank/Climate_ Variability/index.html\#tabs-1

Zurbrügg R, Suter S, Lehmann MF, Wehrli B, Senn DB (2013) Organic carbon and nitrogen export from a tropical damimpacted floodplain system. Biogeosciences 10:23-38. doi:10.5194/bg-10-23-2013 